OAK RIDGE

NATIONAL LABORATORY MANAGED BY UT-BATTELLE

FOR THE DEPARTMENT OF ENERGY

\title{
Montezuma Creek Stability Evaluation at Site of Former Monticello Tailings Pile
}

\author{
N. Korte \\ S. C. Hall \\ G. Pierce \\ J. Zutman
}

M. J. Wilson-Nichols

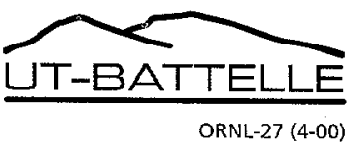




\section{DOCUMENT AVAILABILITY}

Reports produced after January 1, 1996, are generally available free via the U.S. Department of Energy (DOE) Information Bridge.

Web site http://www.osti.gov/bridge

Reports produced before January 1, 1996, may be purchased by members of the public from the following source.

National Technical Information Service

5285 Port Royal Road

Springfield, VA 22161

Telephone 703-605-6000 (1-800-553-6847)

TDD 703-487-4639

Fax 703-605-6900

E-mail info@ntis.fedworld.gov

Web site http://www.ntis.gov/support/ordernowabout.htm

Reports are available to DOE employees, DOE contractors, Energy Technology Data Exchange (ETDE) representatives, and International Nuclear Information System (INIS) representatives from the following source.

Office of Scientific and Technical Information

P.O. Box 62

Oak Ridge, TN 37831

Telephone 865-576-8401

Fax 865-576-5728

E-mail reports@ adonis.osti.gov

Web site http://www.osti.gov/contact.html

This report was prepared as an account of work sponsored by an agency of the United States Government. Neither the United States Government nor any agency thereof, nor any of their employees, makes any warranty, express or implied, or assumes any legal liability or responsibility for the accuracy, completeness, or usefulness of any information, apparatus, product, or process disclosed, or represents that its use would not infringe privately owned rights. Reference herein to any specific commercial product, process, or service by trade name, trademark, manufacturer, or otherwise, does not necessarily constitute or imply its endorsement, recommendation, or favoring by the United States Government or any agency thereof. The views and opinions of authors expressed herein do not necessarily state or reflect those of the United States Government or any agency thereof. 


\author{
Environmental and Life Sciences Division
}

\title{
MONTEZUMA CREEK STABILITY EVALUATION AT SITE OF FORMER MONTICELLO TAILINGS PILE
}

Final Report

\author{
N. Korte, Task Leader \\ M. J. Wilson-Nichols, Project Manager \\ S. C. Hall, Field Team Member \\ G. Pierce, Field Team Member \\ J. Zutman, Field Team Member \\ Environmental Technology Section \\ Grand Junction, Colorado
}

Date Published: January 2001

\author{
Prepared by the \\ OAK RIDGE NATIONAL LABORATORY \\ Oak Ridge, Tennessee 37831 \\ managed by \\ UT-BATTELLE, LLC \\ for the \\ U.S. DEPARTMENT OF ENERGY \\ under contract DE-AC05-00OR22725
}




\section{CONTENTS}

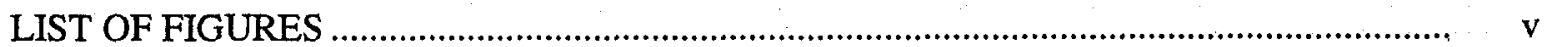

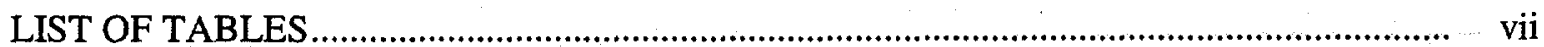

ACRONYMS AND ABBREVIATIONS

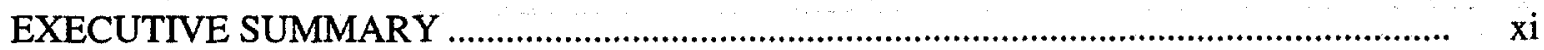

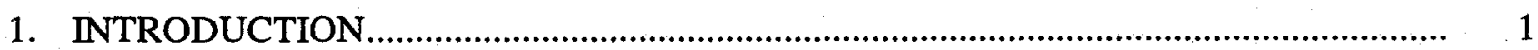

1.1 GEOMORPHIC APPROACH TO STREAM MONITORING ................................ 2

1.2 HISTORICAL CHANGES ON MONTEZUMA CREEK .......................................... 4

2. DESCRIPTION OF FIELD PROGRAM .................................................................... 7

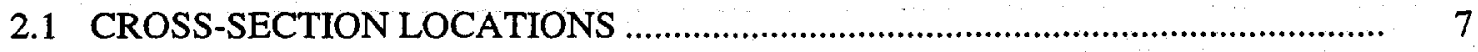

2.1.1 Background/Golf Course ..................................................................... 7

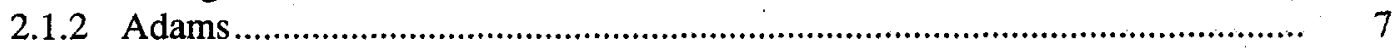

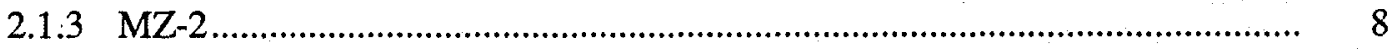

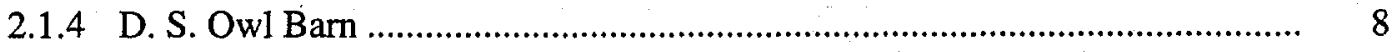

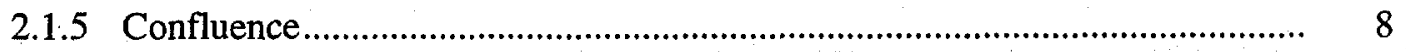

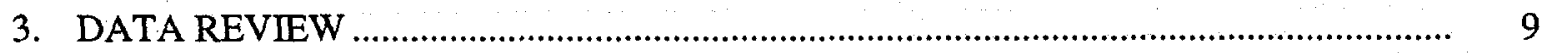

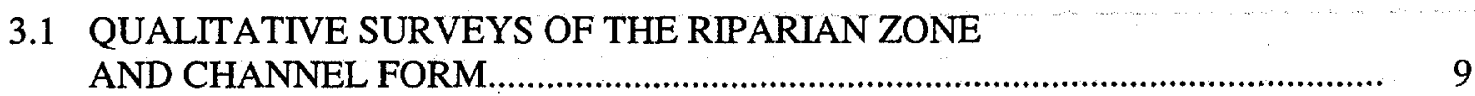

3.1.1 Meander Pattern ................................................................................... 9

3.1.2 Riparian Vegetation ............................................................................... 9

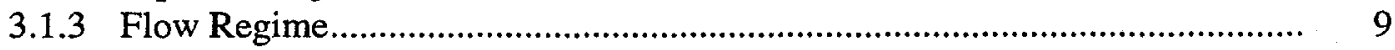

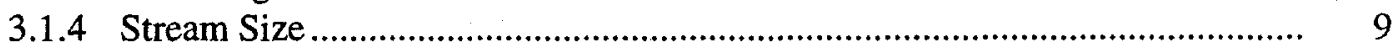

3.1.5 Depositional Features........................................................................... 9

3.1.6 Debris Blockage........................................................................... 13

3.1.7 Pfankuch Evaluation.......................................................................... 13

3.1.8 Bank Erosion Potential .................................................................... 13

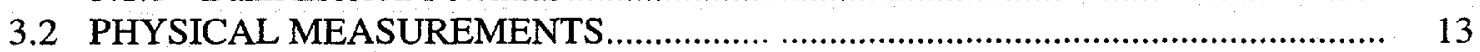

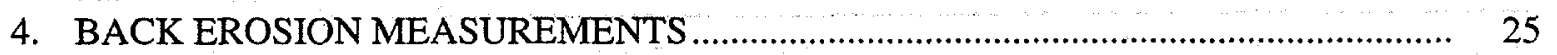

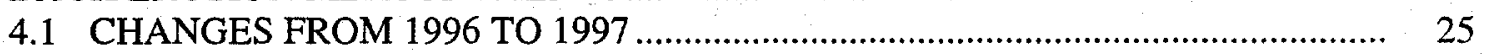

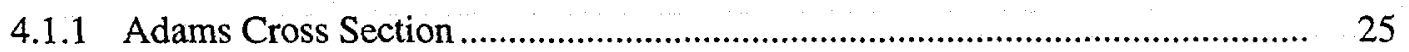

4.1.2 MZ-2 Cross Section ............................................................................. 26.

4.1.3 D. S. Owl Barn Cross Section................................................................... 26

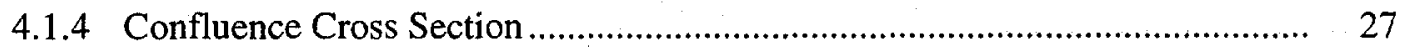

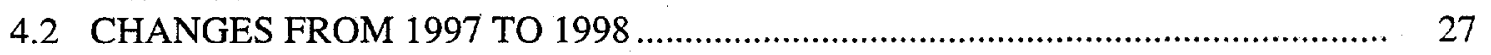

4.2.1 Adams Cross Section ............................................................................ 27

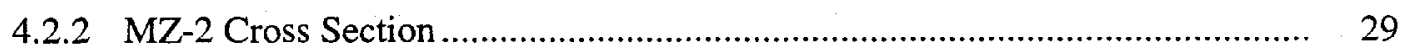

4.2.3 D. S. Owl Barn Cross Section.................................................................... 29

4.2.4 Confluence Cross Section ........................................................................... 29

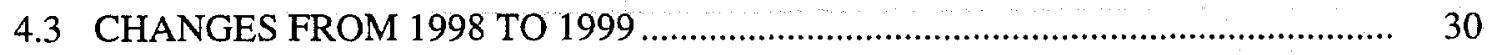

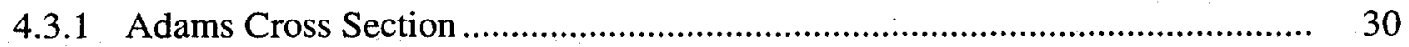

4.3.2 MZ-2 Cross Section ............................................................................ $\quad 30$

4.3 .3 D. S. Owl Barn Cross Section................................................................. 30

4.3.4 Confluence Cross Section ....................................................................... $\quad 30$

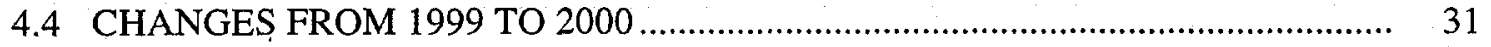

4.4.1 Adams Cross Section .......................................................................... 31

4.4.2 MZ-2 Cross Section ........................................................................... 31 
4.3.3 D. S. Owl Barn Cross Section....................................................................... 31

4.4.4 Conflucnce Cross Section .......................................................................... 31

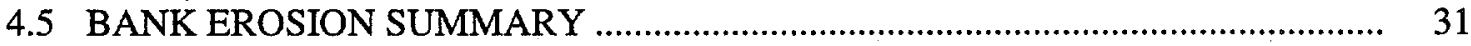

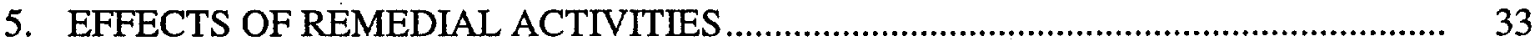

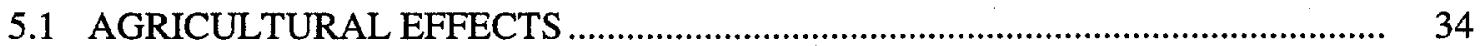

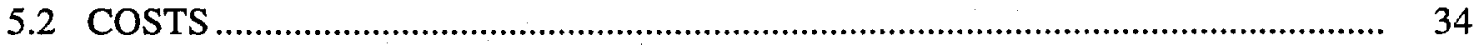

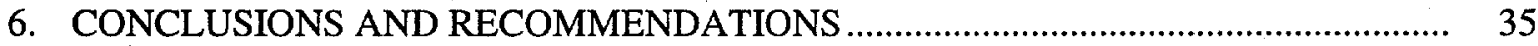

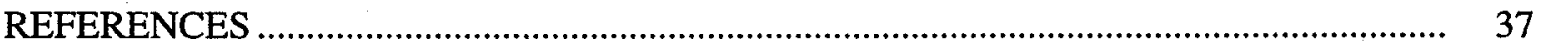




\section{LIST OF FIGURES}

Figure

Page

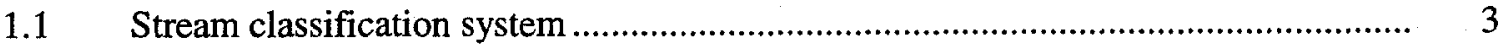

1.2 Channelization and armoring of banks in Montezuma Creek culvert .......................... 4

1.3 Collapsed silt fence during the millsite remedial action .......................................... 5

$2.1 \quad$ Locations of cross sections on Montezuma Creek .................................................... 8

3.1 Streambank near cross section MZ-2 subject to erosion ..................................... 14

3.2 Pebble count data from background site ............................................................... 18

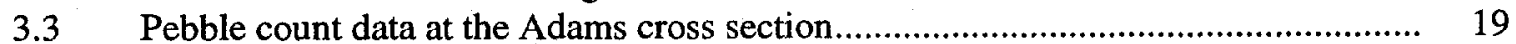

3.4 Pebble count data at the MZ-2 cross section........................................................... 20

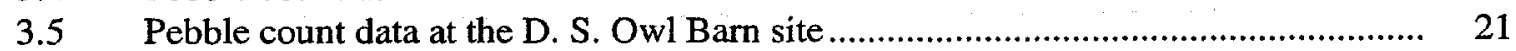

3.6 Pebble count data at the confluence cross section................................................. 22

3.7 Successive changes undergone by an impacted E stream ...................................... 23

4.1 Bank pin showing erosional loss at the Adam's cross section ................................. 25

4.2 Extensive bare stream banks at the MZ-2 cross section ........................................... 26

4.3 Bank pin showing sediment removed at the D. S. Owl Barn location ...................... 26

4.4 Exposed cutbank at the D. S. Owl Barn cross section ........................................... 27

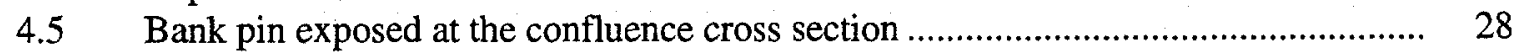

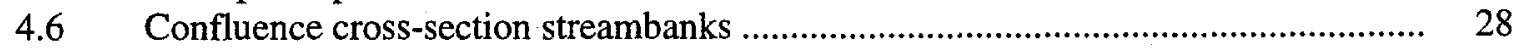

$5.1 \quad$ Exposed bank pin showing effects of remedial activities ....................................... 33

5.2 Collapsed silt fence in Montezuma Creek during remedial activities ........................ 33 


\section{LIST OF TABLES}

\section{Table}

Page

3.1 Visual evaluation of Montezuma Creek stream stability monitoring locations .......... 10

3.2 Comparison of physical measurements at stream stability monitoring locations ....... 15

3.3 Tons of sediment lost per cross section per year based on measurements with bank pins 


\section{ACRONYMS AND ABBREVIATIONS}

$\begin{array}{ll}\text { ARAR } & \text { applicable or relevant and appropriate requirements } \\ \text { BPMs } & \text { best management practices } \\ \text { CERCLA } & \text { Comprehensive Environmental Response, Compensation, and Liability Act } \\ \text { cm } & \text { centimeter } \\ \text { DOE } & \text { U.S. Department of Energy } \\ \text { ETS } & \text { Environmental Technology Section } \\ \mathrm{ft} & \text { foot } \\ \text { in. } & \text { inch } \\ \text { IECA } & \text { International Erosion Control Association } \\ \text { IVC } & \text { Independent Verification Contractor } \\ \text { NAS } & \text { National Academy of Sciences } \\ \text { ORNL } & \text { Oak Ridge National Laboratory } \\ \text { s } & \text { second }\end{array}$




\section{EXECUTIVE SUMMARY}

This report documents the results of an evaluation of stream stability for Montezuma Creek downstream of the former uranium and vanadium millsite at Monticello, Utah. The work was performed by personnel from Oak Ridge National Laboratory's (ORNL's) Environmental Technology Section (ETS). ORNL/ETS was the Independent Verification Contractor (IVC) for the Monticello projects, and it established independent verification strategies that provided the U.S. Department of Energy (DOE) with a third-party assessment of whether remedial action had effectively reduced levels of contamination and whether supporting documentation that described the remediation was adequate.

The DOE regulation 10 CFR 1022, which implements Executive Orders 11988 and 11990 for the protection of wetlands and floodplains, provided the regulatory rationale for the activity. This report documents both the impact of millsite remedial activities and postremediation conditions of Montezuma Creek.

The scicntific rationale for the stream survey was that conventional engincering practices do not adequately account for varying hydrologic regimes nor do they address the entire riparian zone as an interrelated unit. As a result, modifications to streams consistently cause damage to the environment by increasing erosion and sedimentation.

Field activities included the establishment of permanent cross sections and periodic measurements and surveys of physical characteristics. The data demonstrated an increase in downstream stream bank erosion when activities at the millsite were greatest. Note, however, that agricultural practices have also contributed to erosion and bank instability. Nevertheless, an increase in fine sediment and bank recession were correlated to the construction.

In addition, the project documented the failure of best management practices such as silt fences, to control sediment loss. Furthermore, conventional engineering designs were used to reroute Montezuma Creek, an action that will require increased maintenance when compared to a natural channel. Although these latter actions remain the most common practices, it is recommended that DOE apply geomorphic designs at future sites. 


\title{
MONTEZUMA CREEK STABILITY EVALUATION MONTICELLO TAILINGS PILE
}

\author{
N. Korte, Task Leader \\ M. J. Wilson-Nichols, Project Manager \\ S. C. Hall, Field Team Member \\ G. Pierce, Field Team Member \\ J. Zutman, Field Team Member
}

\section{INTRODUCTION}

The purpose of this report is to document observations and measurements obtained from 1996 through 2000 regarding the stability of Montezuma Creek downgradient of the former Monticello millsite in Monticello, Utah. The Monticello millsite was the location of a uranium and vanadium mill that was constructed in the 1930s and remained active until the early 1960s. Radioactive tailings that were deposited on both sides of Montezuma Creek resulted in contamination of both the stream and the alluvial aquifer. The U.S. Department of Energy (DOE) has completed cleanup and removal of these tailings. Excavation of tailings occurred on adjacent properties and within the stream course, in addition to the millsite itself.

Oak Ridge National Laboratory's (ORNL's) Environmental Technology Section (ETS) was the Independent Verification Contractor (TVC) for the Monticello projects, and it established independent verification strategies that provided the DOE with a third-party assessment of whether remedial action had effectively reduced levels of contamination and whether supporting documentation describing the remediation was adequate (ORNL 1992, ORNL 1998). The rationale for this survey of stream stability was threefold, encompassing regulatory, scientific, and engineering considerations.

The regulatory rationale for the stream stability survey is found in DOE regulation 10 CFR 1022, which implements Executive Orders 11988 and 11990 for the protection of wetlands and floodplains. DOE actions under Superfund are not required to comply with the 10 CFR 1022 requirement for assessment of the potential impacts of an action on a wetland or floodplain, but these executive orders are among the "substantive" environmental requirements with which Comprehensive Environmental Response, Compensation, and Liability Act (CERCLA) actions must comply [i.e., applicable or relevant and appropriate requirements (ARARs)]. Activities that affect the creek and associated wetlands, therefore, are addressed by these regulations. This report documents the impact of the remedial activities on the creek, and it documents postremediation conditions as well.

The scientific rationalc for the stream survey was that conventional enginccring practices do not adequately account for varying hydrologic regimes nor do they address the entire riparian zone as an interrelated unit. As a result, modifications to streams consistently cause significant damage to the environment by increasing erosion and sedimentation. This problem is caused by lack of suitable training in fluvial geomorphology. For example, an official with the U.S. Army Corps of Engineers noted at a recent workshop that whenever one is confronted with concerns for the safety of floodplain development, one should "raise the levee" (Stakhiv 1996). This statement was made despite the fact that contemporary research and the enormous damage caused by recent floods have shown that "hard fixes" (e.g., concrete, rip-rap, dikes, and levees) eventually cause more damage 
than they prevent (Rosgen 1997). Moreover, hard fixes always require long-term maintenance. Thus, while initial costs may be low, long-term costs are high and unpredictable, and such projects are always damaging to the environment.

Fortunately, the engineering community is becoming increasingly aware that many best management practices (BMPs) are ineffective. A prominent example is the use of straw bale check dams. As noted in a recent project review, of straw bale check dams that "were installed properly according to agency-approved design criteria, approximately $60 \%$ had failed" (IECA 1998). Similarly, diversions and run-on/run-off controls frequently handle sediment inadequately and alter the stream hydrograph to such an extent that severe environmental damage occurs. Indeed, sediment loads from construction projects can be 2000 times those from wooded land, 200 times greater than pasture, and 10 to 20 times greater than cultivated land. Considering that the millsite activity was a large construction project bisected by a perennial stream, documentation regarding how construction affected the stream was an appropriate aspect of the IVC function.

\subsection{GEOMORPHIC APPROACH TO STREAM MONITORING}

Large, engineering, construction projects typically give little attention to stream stability. The problem is described in the following quote from Luna Leopold, perhaps, the most eminent surface water hydrologist to practice in the United States.

In modern science there is always some tension between the theoretical and the practical application of basic knowledge. The pressures of development and the desirc of the present society for profits at the expense of anything natural, wild or free has degraded landscapes throughout the world by river engineering, river straightening, construction of levees, dams, and concrete channels. These actions have been the essence of our approach to problems of flood control, navigation, irrigation, hydroelectric development, municipal and industrial water needs, even though at the same time much has been learned about river mechanics, geomorphology, hydraulics, and sedimentation. Despite the new knowledge, the traditional engineering approach to river development has not only dominated valley land management, but has failed to incorporate the practical, physical, aesthetic, and financial advantages of approaching river management as maintenance of natural tendencies in river channel behavior (Leopold 1996).

Traditionally, engineers use what is called the "unit hydrograph approach." This approach is a design for floods, not forbankfull, although it is at bankfullwhen most sediment is moved and when channel formation and maintenance occurs. The result is a trapezoidal channel that is too wide and too straight. Such a channel cannot move sufficient sediment and aggrades. A more specific example is the critical dimensionless shear stress-a parameter used to ensure that designed channels can move the bed sediment supplied naturally by the surrounding terrain. When actual field measurements are made, one finds that the relationships provided in design tables in the Army Corps of Engineers handbook (USACE 1994) are not effective for many streams (Rosgen 1997). The result of using the engineering tables rather than measured values based on a geomorphic understanding of the river is that accumulation of sediment causes channel braiding, widening, and bank erosion. Persistent problems with engineered channels have led to the use of the geomorphic approach for stream classification and monitoring. The basis of the geomorphic approach is the stream classification system shown in Fig. 1.1 (Rosgen 1994). The data in Fig. 1.1 were derived from numerous field measurements and represent a continuum of physical variables. These physical variables encompass all aspects of the stream's pattern. For example, Fig. 1.1 demonstrates that there is a well-defined relationship between the sinuosity and the valley 


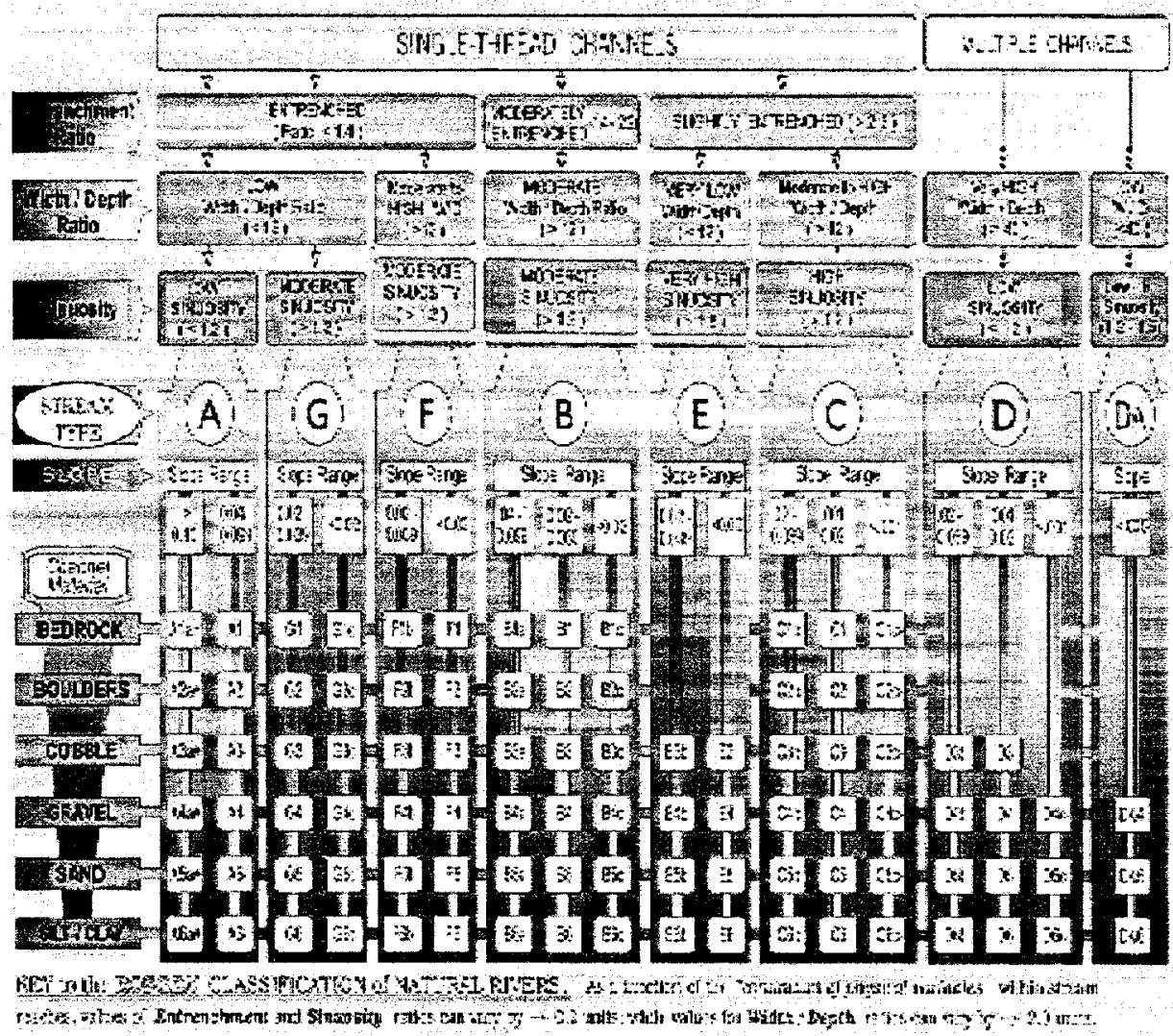

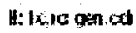

Fig. 1.1. Stream classification system (Rosgen 1996).

slope-demonstrating immediately that channelized streams cannot function naturally. The efficacy of the geomorphic approach has been recognized by the National Academy of Sciences (NAS). In a review of a restoration project using the geomorphic approach, the NAS stated that "the project suggests that the natural tendencies of rivers are predictable based on their morphology, substrate, surrounding landforms and flow rates" (NRC 1992). Conversely, designs that do not encompass all of these variables always cause environmental damage.

Application of the geomorphic approach differs from conventional engineering in two major ways. The most important difference, as with the critical dimensionless shear stress mentioned above, is that extensive field measurements are required. Engineering tables are not used without obtaining field verification. Instead, sediment relationships and channel dimensions are measured at the restoration site and at a reference site, and these field data are used for the design. Designing for bankfull rather than for floods is the second major distinction from traditional engineered approaches. As noted previously, the significance of designing for bankfull is that it is the river stage when most sediment movement and channel maintenance occurs. Hence, a channel designed to maintain the appropriate bankfull dimensions for a particular hydrologic regime will be a stable channel. Once bankfull dimensions are designed, sufficient floodplain is included so that floods are managed effectively. In summary, the geomorphic approach requires more fieldwork before channel design can be completed, and it addresses not just peak discharge, but includes a quantitative evaluation and design with regard to sediment movement and maintenance of channel form. This approach provides a framework for assessing a stream's stability and response to construction within the watershed. Consequently, the monitoring described in this report was performed according to geomorphic principles. 


\subsection{HISTORICAL CHANGES ON MONTEZUMA CREEK}

Although there is little historic record regarding how past land use practices have affected Montezuma Creek, millsite and agricultural activities have occurred for at least 60 years. In addition, a dam and reservoir upstream of the millsite have more recently affected the watershed. Such activities usually cause significant changes.

The costs of poorly designed construction activities relative to streams are illustrated by the fact that approximately six billion tons of soil erode from the nation's lands each year. It is estimated that sediment and sediment-related pollution cause $\$ 3.7$ to $\$ 14$ billion in damages each year in the United States, including loss of farm productivity (Clark et al. 1985, Colacicco et al. 1989). This is a concern at Monticello where any loss of pasture and crop land through erosion results in a cost to the farmers and ranchers downstream of the millsite.

Construction usually includes channelization, armoring banks (Fig. 1.2), and higher peak flows. These changes cause higher velocity flows that incise the channel. That the original millsite operations caused such problems was shown by the presence of a grade control structure at the downgradient boundary. This grade control structure was installed to limit further headcutting of the channel. Incision such as had occurred causes long-term morphological transformations at the landscape scale and has greater potential for degrading biotic integrity than point-source or nonpoint-source pollution (Karr 1991). Examples of the problems caused by channelization and incision are numerous in the southwestern United States. A nearby example is the Alamosa River near Alamosa, Colorado-a small, high altitude community that can be compared to Monticello. "Channelization of the Alamosa River resulted in scouring of a deeper channel, as the river dropped, so did the water table which desiccated the plant community. Stream banks collapsed. Roads, bridges, etc., were and continue to be damaged" (Stern 1998).

Another frequent effect of construction is that a stream cannot carry the sediment load. The sediment is deposited in the bed and floodplain. Channel braiding occurs, a locally convex profile develops, and bank erosion increases (Ferguson 1991). This effect can be observed in the recently

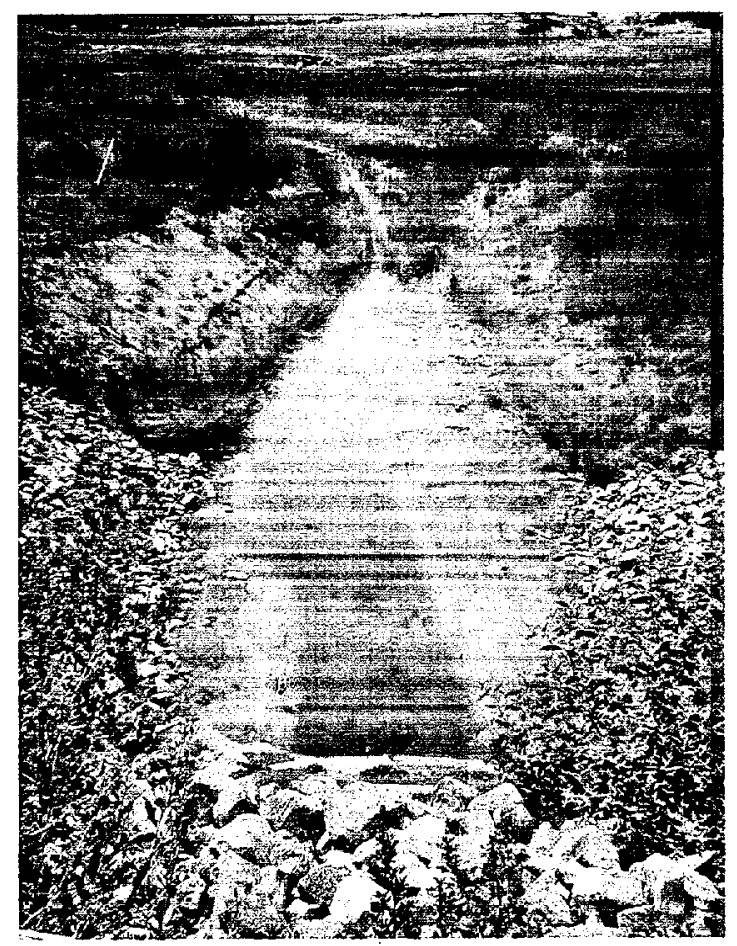

Fig. 1.2. Channelization and armoring of banks in Montezuma Creek culvert. 
channelized section of Montezuma Creek (Fig. 1.2). The bare stream banks are contributing fine sediment that will accumulate elsewhere in the watershed and hinder aquatic life. Studies at other former mining and milling areas have shown that erosion of previously contaminated banks can become the chief contributor of contamination to a stream (Miller et al. 1998). Indced, crosion redistributed the radioactive tailings deposited along Montezuma Creek. Radioactive contaminants were irregularly distributed for miles downstream. Expensive and environmentally damaging remedial action was required to remove these tailings (Fig. 1.3).

The high turbidity caused by bank erosion and increased sediment supply also limits light penetration and inhibits plant growth and sight-feeding fish. Microbial populations are suppressed as much as three orders of magnitude (Hey et al. 1989). This lower productivity means lower overall biomass, including sport fish. For example, trout have been collected in Verdure Creek, just south of Monticello and at a similar elevation, even though the watershed is smaller (Smith et al. 1996).

A loss in productivity also impairs a stream's ability to cleanse itself. Natural microbial activity is generally the least expensive approach for removing contaminants. Montezuma Creek downgradient from the millsite has already been shown to have a degraded benthic environment (Smith et al. 1996). Thus, a creek's ability to remove agricultural contamination (pesticides, herbicides, and animal wastes) is inhibited if its physical condition is degraded.

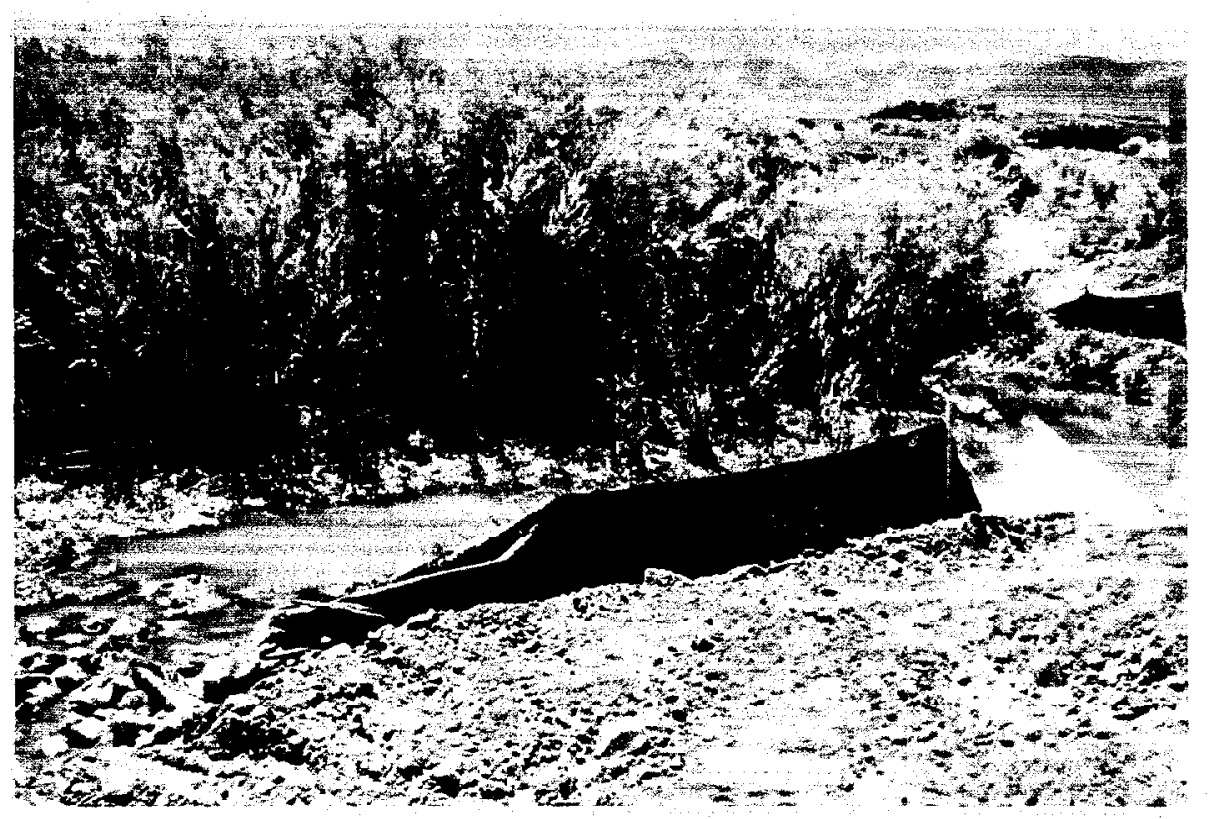

Fig. 1.3. Collapsed silt fence during the millsite remedial action. 


\section{DESCRIPTION OF FIELD PROGRAM}

The field program for Montezuma Creek consisted of monitoring stream cross sections at several locations above and below the millsite. In this way, changes that occurred upstream of the millsite could be separated from those occurring downstream. Furthermore, enough cross sections were evaluated downstream to evaluate the distance affected by millsite activities.

Typical flow rates through the project area are $1 \mathrm{ft}^{3} / \mathrm{s}$. Peak flows during spring runoff may attain $30 \mathrm{ft}^{3} / \mathrm{s}$. Flow is generally perennial although some sections are seasonally dry (DOE 1998).

The following activities were conducted at each cross section.

- The location was surveyed so that the bankfull dimensions could be obtained. The bankfull is important, as noted above, because that is the discharge that forms and maintains the channel. The surveyed cross sections provided a year-to-year record of changes occurring in channel dimensions and form. For example, an increasing width-to-depth ratio indicates degradation of the habitat.

- Pebble counts were performed at each cross-section location to document the channel substrate (Rosgen 1996). Changes in the substrate from above to below the millsite would indicate stream deterioration caused by the millsite construction.

- A qualitative survey of the riparian zone and of the channel form was performed. This survey provided a convenient means for describing the overall stability of the reach and for documenting year-to-year changes.

- Bank pins were installed at selected locations to measure the amount of bank erosion. (Note: bank pins were not installed upstream of the millsite because the banks are well armored with natural rock and show no sign of instability.)

\subsection{CROSS SECTION LOCATIONS}

Five general locations were used for cross-sectional measurements. The locations were selected to obtain data upstream of millsite activities, at locations spaced between the millsite and Montezuma Creek's confluence with Vega Creek, and at the confluence of Montezuma and Vega Creek. The locations of the cross sections are shown on Fig. 2.1 and are described below.

\subsubsection{Background/Golf Course}

This location, which serves as the background site, is upstream of Highway 191, just downstream of the golf course (approximately $1668 \mathrm{ft}$ from the millsite). Although not pristine, this vicinity is more realistic for background than sites above the golf course where the topographic relief is much greater.

\subsubsection{Adams}

This location is approximately $2394 \mathrm{ft}$ downstream from the millsite boundary. Three cross sections (upstream, center, and downstream) were used to document an entire bend ( $1 / 2$ wavelength) in the stream. The measurements were taken upgradient of a stream crossing and culvert installed by the land owner. The location was selected because it is the first major bend in the stream below the millsite. 


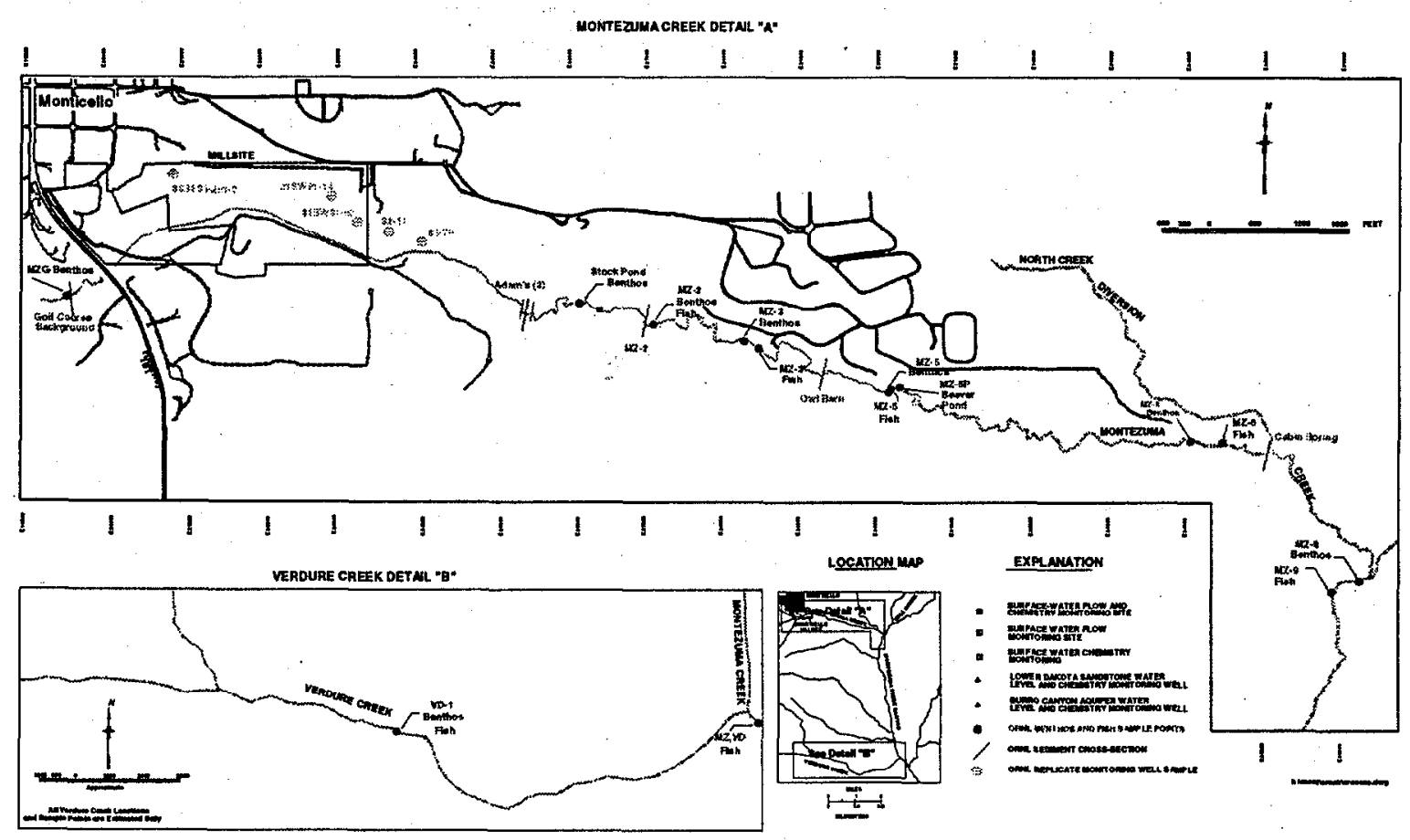

Fig. 2.1. Locations of cross sections on Montezuma Creek.

\subsubsection{MZ-2}

This location is approximately $4596 \mathrm{ft}$ downstream of the millsite and coincides with a former benthic study sampling location (Smith et al. 1996). This area was also subject to significant remediation in 1998.

\subsubsection{S. Owl Barn}

This location is approximately $8113 \mathrm{ft}$ downstream of the millsite. The site is just downgradient of some exposed bedrock in the streambed and upgradient of a small spring-fed wetland. Although remediation of the channel did not occur within the (bankfull) cross section, significant soil and sediment removal occurred within the floodplain and in the spring/wetland area just downstream.

\subsubsection{Confluence}

This site is located $15,238 \mathrm{ft}$ downstream of the millsite, just upstream from Montezuma Creek's confluence with Vega Creek. This site was not expected to show much effect from the construction both because of the distance from the millsite and the fact that the site is downgradient of a section where the creek narrows and bedrock exerts control over the stream's pattern. 


\section{DATA REVIEW}

\subsection{QUALITATIVE SURVEYS OF THE RIPARIAN ZONE AND CHANNEL FORM}

Table 3.1 presents a comparison of the visual surveys performed during each stream stability monitoring trip. The forms used to conduct the surveys are presented in Rosgen 1996. The completed forms are available for inspection in the project files. They were not appended to minimize reproduction costs of this report.

\subsubsection{Meander Pattern}

In contrast to the downstream locations, the meander pattern at the background cross section did not change during the survey period. At the other locations, an irregular pattern was indicated by the 1996 survey with regular patterns thereafter. Such a simplification in the meander pattern is an indication of downcutting and deterioration of the channel. These data are only suggestive, however, because they are based on visual interpretations and because the data record is so brief.

\subsubsection{Riparian Vegetation}

The riparian vegetation at the background site was characterized as high-density/deciduous with a brush/grass understory throughout the survey period. All of the downstream cross sections, except the confluence, show degradation in riparian vegetation during the remediation period (through 1998). The changes are typified by the data from the MZ-2 location that was described as moderate density grass/brush in 1996, moderate density low brush in 1997, and bare in 1998. The bare ground observed in 1998, however, was a consequence of remediation that had recently been performed. Nevertheless, each site showed a transition to a lower density, less robust vegetative regime. These changes may result from contaminant removal as at MZ-2 or from livestock use, which appeared to be the probable cause at the Adams locations and at the confluence in 1999/2000. Note that considerable recovery had occurred at MZ-2 by 2000.

\subsubsection{Flow Regime}

The stream was flowing during all survey periods and is, therefore, classed as perennial dominated primarily by snowmelt runoff.

\subsubsection{Stream Size}

The stream size is classified as $S-3$, meaning the bankfull width is 5 to $15 \mathrm{ft}$. In contrast, the confluence location is relatively close to an $S-2$ classification (bankfull $<5 \mathrm{ft}$ ), and portions of the Adams, MZ-2, and D. S. Owl Barn locations are approaching S-4 (bankfull> $15 \mathrm{ft}$ ).

\subsubsection{Depositional Features}

The survey of depositional features is a qualitative assessment of sediment accumulation. An increase in midchannel bars is a sign that the stream is not competent to remove added sediment. These data are inconclusive with respect to a trend. Midchannel bars were noted at several locations during the first and third years of the survey. Survey notes, however, indicate indecision with respect to bar formation in the 1996 survey, while the 1998 survey noted that bars were very obvious. These data, therefore, are suggestive of channel deterioration during remediation. By 2000 , midchannel bars were no longer noted. 
Table 3.1. Visual evaluation of Montezuma Creek stream stability monitoring locations ${ }^{a}$

\begin{tabular}{|c|c|c|c|c|c|c|c|c|c|}
\hline Location & Date & $\begin{array}{l}\text { Meander } \\
\text { pattern }\end{array}$ & $\begin{array}{l}\text { Riparian } \\
\text { vegetation }\end{array}$ & $\begin{array}{l}\text { Flow } \\
\text { regime }\end{array}$ & $\begin{array}{l}\text { Stream } \\
\text { size }\end{array}$ & $\begin{array}{l}\text { Depositional } \\
\text { features }\end{array}$ & $\begin{array}{c}\text { Debris } \\
\text { blockage }\end{array}$ & $\begin{array}{l}\text { Pfankuch } \\
\text { evaluation }\end{array}$ & $\begin{array}{c}\text { Bank erosion } \\
\text { potential }\end{array}$ \\
\hline Background & $10 / 96$ & M-1 & $10 \mathrm{c}$ & $\mathrm{P}-1$ & S-3 & B-1 & $\mathrm{D}-2$ & 44 (good) & $14(10 w)$ \\
\hline Background $^{b}$ & $08 / / 97$ & M-1 & $10 \mathrm{c}$ & $P-1$ & $S-3$ & B-1 & $\mathrm{D}-2$ & 44 (good) & 14 (low) \\
\hline Background & $09 / 98$ & M-1 & $10 \mathrm{c}$ & P-1 & $S=3$ & $\mathrm{~B}-2$ & $\mathrm{D}-2$ & 44 (good) & 15 (low) \\
\hline Background & $12 / 99$ & M-1 & $10 \mathrm{c}$ & P-1 & $S-3$ & B-2 & D-2 & 44 (good) & 15 (low) \\
\hline Background & $07 / 00$ & M-1 & $10 \mathrm{c}$ & P-1 & $S-3$ & B-2 & D-2 & 44 (good) & 15 (low) \\
\hline Adams upstream & $10 / 96$ & M-3 & $8 b$ & P-1 & $S-3$ & $\mathrm{~B}-2 ?$ & D-1 & 62 (good) & 16 (low) \\
\hline Adams upstream & \multicolumn{9}{|c|}{ Location not evaluated in 1997} \\
\hline Adams upstream & $09 / 98$ & M-1 & $3 b$ & P-2 & S-3 & B1 & D-1 & 67 (fair) & 12 (low) \\
\hline Adams upstream & $\begin{array}{l}\text { Location not } \\
\text { evaluated in } \\
1998,1999 \text {, } \\
\text { or } 2000 \\
\end{array}$ & & & & & & & & \\
\hline Adams center & $10 / 96$ & M-3 & $8 b$ & P-1 & $S-3$ & B-2? & D-1 & 128 (poor) & 44 (very high) \\
\hline Adams center & $08 / 97$ & M-1 & $\begin{array}{l}\text { 3c-left bank, } \\
\text { 8c-right } \\
\text { bank }\end{array}$ & P-1/P-2 & S-3 & B-1 & D-2 & 132 (poor) & 39.5 (high) \\
\hline
\end{tabular}


Table 3.1. (continued)

\begin{tabular}{|c|c|c|c|c|c|c|c|c|c|}
\hline Location & Date & $\begin{array}{l}\text { Meander } \\
\text { pattern }\end{array}$ & $\begin{array}{c}\text { Riparian } \\
\text { vegetation }\end{array}$ & $\begin{array}{l}\text { Flow } \\
\text { regime }\end{array}$ & $\begin{array}{l}\text { Stream } \\
\text { size }\end{array}$ & $\begin{array}{l}\text { Depositional } \\
\text { features }\end{array}$ & $\begin{array}{c}\text { Debris } \\
\text { blockage }\end{array}$ & $\begin{array}{l}\text { Pfankuch } \\
\text { evaluation }\end{array}$ & $\begin{array}{c}\text { Bank erosion } \\
\text { potential }\end{array}$ \\
\hline Adams center & $09 / 98$ & M-1 & $3 b$ & P1 & S-3 & B-1 & D-1 & 138 (poor) & 44 (very high) \\
\hline Adams center & $12 / 99$ & M-1 & $3 a$ & P1 & $S-3 / S-4$ & B-2 & $\mathrm{D}-2$ & 143 (poor) & 48 (very high) \\
\hline Adams center & $07 / 00$ & $\begin{array}{l}\text { Not } \\
\text { evaluated in } \\
2000 \\
\end{array}$ & & & & & & & \\
\hline Adams downstream & $10 / 96$ & M-3 & $8 b$ & $\mathrm{P}-1$ & S-3 & B-2? & D-1 & 128 (poor) & 44 (very high) \\
\hline Adams downstream & \multicolumn{9}{|c|}{ Location not evaluated in $1997,1998,1999,2000$ (similar to Adams center) } \\
\hline $\mathrm{MZ}-2$ & $10 / 96$ & M-3 & $8 b$ & P-1 & $S-3 / S-4$ & B-2 & D-1 & 117 (poor) & 47 (extreme) \\
\hline MZ-2 & $08 / 97$ & M-1 & $6 \mathrm{~b}$ & P-1/P-2 & $S-3$ & B-1 & D-1 & 123 (poor) & 46 (extreme) \\
\hline MZ-2 & $09 / 98$ & M-1 & RV-1 & P-1 & S-3 & B-2 & D-2 & 140 (poor) & 40 (very high) \\
\hline MZ-2 & $12 / 99$ & M-1 & $3 a$ & P-1 & S-3 & B-2 & D-2 & 110 (fair) & 24 (moderate) \\
\hline MZ-2 & $07 / 00$ & M-1 & $3 c$ & P-1 & S-3 & B-1 & D-1 & 110 (fair) & 24 (moderate) \\
\hline D. S. Owl Barn & $10 / 96$ & M-3 & $8 b$ & P-1 & $S-4$ & B-2 & D-1 & 116 (poor) & 46 (extreme) \\
\hline D. S. Owl Barn & $08 / 97$ & M-1 & $6 \mathrm{~b}$ & P-1/P-2 & $S-4$ & B-1 & D-2 & 122 (poor) & 43 (very high) \\
\hline
\end{tabular}


Table 3.1. (continued)

\begin{tabular}{|c|c|c|c|c|c|c|c|c|c|}
\hline Location & Date & $\begin{array}{l}\text { Meander } \\
\text { pattern }\end{array}$ & $\begin{array}{c}\text { Riparian } \\
\text { vegetation }\end{array}$ & $\begin{array}{l}\text { Flow } \\
\text { regime }\end{array}$ & $\begin{array}{l}\text { Stream } \\
\text { size }\end{array}$ & $\begin{array}{l}\text { Depositional } \\
\text { features }\end{array}$ & $\begin{array}{c}\text { Debris } \\
\text { blockage }\end{array}$ & $\begin{array}{l}\text { Pfankuch } \\
\text { evaluation }\end{array}$ & $\begin{array}{c}\text { Bank erosion } \\
\text { potential }\end{array}$ \\
\hline D. S. Owl Barn & $09 / 98$ & M-1 & $3 a / 7 b$ & P-1 & S-3 & B-2 & D-2 & 122 (poor) & 44 (very high) \\
\hline D. S. Owl Barn & $12 / 99$ & M-1 & $8 b$ & P-1 & S-3 & B-2 & D-2 & 110 (fair) & 40 (very high) \\
\hline D. S. Owl Barn & $07 / 00$ & M-1 & $8 b$ & P-1 & S-3 & B-2 & D-2 & 110 (fair) & 40 (very high) \\
\hline Confluence & $10 / 96$ & M-3 & $8 a$ & P-1 & S3 & B-1 & $\mathrm{D}-1$ & 87 (fair) & 38 (high) \\
\hline Confluence & $08 / 97$ & M-1 & $5 b$ & $\mathrm{P}-1 / \mathrm{P}-2$ & S-3 & B-1 & D-2 & 69 (good) & 38 (high) \\
\hline Confluence & $09 / 98$ & M-1 & $8 \mathrm{~b}$ & P-1 & S-3 & B-1 & D-1 & 74 (good) & 25 (moderate) \\
\hline Confluence & $12 / 99$ & M-1 & $3 a$ & P-1 & $S-3$ & B-1 & D-2 & 86 (fair) & 31 (high) \\
\hline Confluence & $07 / 00$ & M-1 & $3 a$ & P-1 & S-3 & B-1 & $D-2$ & 86 (fair) & 25 (moderate) \\
\hline
\end{tabular}

\section{"Meander patterns:}

M-1: Regular meander, and M-3: Irregular meander.

\section{Riparian vegetation:}

3c: Annual grass with forbs-high density

6b: Low brush-moderate density

8a: Combination grass/brush-low density

8b: Combination grass/brush-moderate density

8c: Combination grass/brush-high density

10c: Deciduous with brush/grass understory-high density

\section{Flow regime:}

P-1: Perennial stream channels. Surface water persists year long. Seasonal variation in streamflow dominated primarily by snowmelt runoff.

P-2: Perennial stream channels. Surface water persists year long. Seasonal variation in streamflow dominated primarily by stormflow runoff.

\section{Stream size:}

S-3: Bankfull width 1.5 to $4.6 \mathrm{~m}(5$ to $15 \mathrm{ft}$ ).

S-4: Bankfull width 4.6 to $9 \mathrm{~m}$ (15 to $30 \mathrm{ft})$.

Depositional features:

B-1: Point bars, and B-2: Point bars with few midchannel bars.

\section{Debris blockage:}

D-1: None. Minor amounts of small, floatable materials.

D-2: Infrequent-debris consists of small, easily moved, floatable material (i.e., leaves, needles, small limbs, twigs).

${ }^{b}$ New ratings were not performed. The information was assumed to be the same as the 10/96 results—or-not evaluated in $1997,1998$. 


\subsubsection{Debris Blockage}

Debris blockage is an evaluation of the stream's ability to move materials through the channel and is also a descriptor for certain stream types and vegetative cover. In this case, the infrequent debris at the background site is a consequence of the dense vegetation and the deposition of branches into the stream. At the downstream locations, there is no contribution from overhead or streamside vegetation, and the debris blockage consisted of fine sediment, which had trapped small debris and created blockages. Such observations at the Adams, MZ-2, and D. S. Owl Barn in 1997 or 1998 are suggestive of loss of stream competence and/or channel deterioration. Improvement in these conditions was noted during the 1999 and 2000 surveys.

\subsubsection{Pfankuch Evaluation}

The Pfankuch evaluation is a rating system of stream condition and departure from natural conditions. "Good" is the best rating possible, and "poor" the worst. Poor ratings indicate a stream with obvious signs of instability. As shown by Table 3.1, the background, Adam's upsteam, and confluence sites have ratings of "good." The Adams "center" and "downstream" cross sections, MZ-2, and D. S. Owl Barn locations all score in the "poor" range, although MZ-2 improved somewhat postremediation. In general, the poor ratings in Montezuma Creek are a consequence of significant mass wasting and the lack of vegetative protection on the banks. The D. S. Owl Barn location is in such poor condition that it is difficult to discern a trend. Nevertheless, the numerical scores for the Adams, MZ-2, and D. S. Owl Barn sites suggest increasing degradation during millsite remediation. Numerical scores indicated no change at the background location and some improvement at the confluence cross section. The confluence and Adams sections underwent significant deterioration in 1998/1999 as a consequence of livestock use.

\subsubsection{Bank Erosion Potential}

This evaluation focuses only on the potential for sediment addition from the stream banks (Table 3.1). The background site showed low erosion potential because the bank angle is not steep and the banks are protected with rocks and vegetation. In contrast, the steep, often overhanging banks at the Adams center and downstream cross sections, at MZ-2, and D. S. Owl Bam all re'sult in ratings from high to extreme. The confluence cross section remains susceptible to erosion because of the steep banks. The apparent improvement at MZ-2, as based on the numerical score. is a consequence of the large amount of sediment that has fallen since the surveys began and revegetation that has occurred postremediation. The fallen sediment at MZ-2 has reduced the hank angle and the potential for additional erosion in the short term. Much of the streambank in this area, however, remains highly susceptible to erosion (Fig. 3.1).

\subsection{PHYSICAL MEASUREMENTS}

Table 3.2 shows data comparing the physical measurements for each location.

1. Entrenchment ratio-The entrenchment ratio is used to classify the stream according to the scheme presented in Fig. 1.1. More data are needed to determine whether there is a significant trend associated with this measurement. 


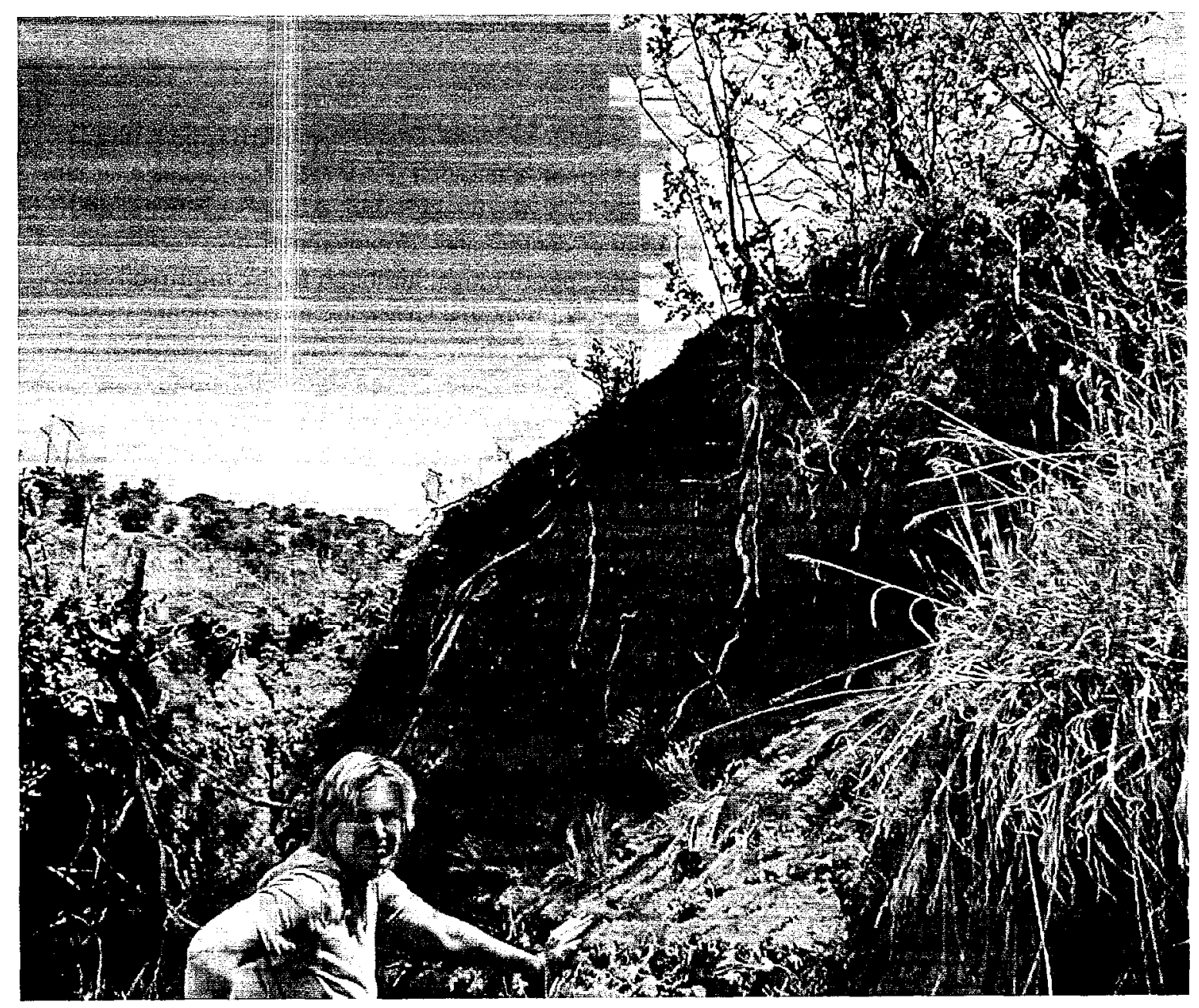

Fig. 3.1. Streambank near cross section MZ-2 subject to erosion. 


\begin{tabular}{|c|c|c|c|c|c|c|c|c|c|c|c|c|c|c|c|c|c|c|c|c|c|}
\hline 岕 & 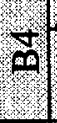 & 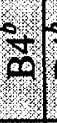 & 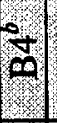 & & 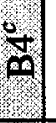 & 占 & 占 & 备 & $\mathrm{Ial}$ & 8 & $8]^{8}$ & 3 & 8 & ن & 1 & 8 & & & a & & 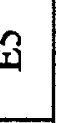 \\
\hline 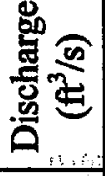 & (1) & 7 & & 1 & 1 & 1 & 1 & 1 & & त) & 1 & & $\begin{array}{l}1 \\
3 \\
\end{array}$ & 1 & 1 & 1 & rat & 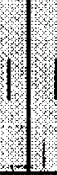 & & & 1 \\
\hline 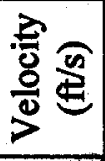 & 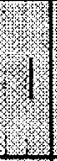 & 9 & 1 & & 1 & 1 & 1 & 1 & & 8 & & & $i$ & 1 & 1 & 1 & 8 & & & & 1 \\
\hline$\frac{n}{a}$ & $\frac{0}{8}$ & 1 & 6 & $\frac{9}{8}$ & $\frac{9}{8}$ & 1 & 1 & 忢 & $\begin{array}{l}5 \\
5 \\
5\end{array}$ & $\begin{array}{l}3 \\
0 \\
\end{array}$ & $\begin{array}{l}\frac{3}{0} \\
\\
\end{array}$ & $\frac{8}{5}$ & 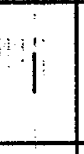 & 1 & 疍 & \begin{tabular}{|l|} 
\\
\\
5
\end{tabular} & 8 & ) & & & 胥 \\
\hline ํㅗㅇ & 8 & 1 & 通 & 9 & 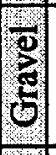 & 1 & $1^{-1}$ & 疍 & ชิ & 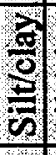 & $\frac{7}{8}$ & ? & 1 & 1 & $\frac{3}{\frac{3}{0}}$ & 造 & 路 & $\begin{array}{ll}9 \\
9 \\
3\end{array}$ & $\frac{3}{8}$ & & 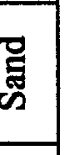 \\
\hline ลั & $\frac{8}{6}$ & 1 & 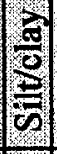 & $\begin{array}{l}\frac{2}{0} \\
\\
5\end{array}$ & \% & 1 & 1 & 蛋 & की & $\begin{array}{l}\frac{\pi}{0} \\
\frac{0}{0} \\
\end{array}$ & $\frac{3}{5}$ & $\frac{8}{8}$ & 1 & 1 & $\frac{\frac{\mathrm{a}}{3}}{\frac{D}{5}}$ & 章 & $\frac{\mathrm{t}}{\mathrm{s}}$ & $\begin{array}{lll}3 \\
0 \\
0\end{array}$ & & & 完 \\
\hline 용 & 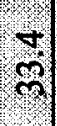 & 9 & $m$ & 1 & 1 & $\ddot{8}$ & 1 & $\ddot{\circ}$ & : & ते & ? & & $\ddot{8}$ & 1 & ڤே & 람 & $\frac{5}{6}$ & 2. & 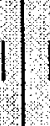 & & $\frac{a}{n}$ \\
\hline$\underset{\mathbb{E}}{\mathbb{2}} \stackrel{0}{\mathrm{e}}$ & 8 & 8 & f & 1 & 1 & $\hat{n}$ & 1 & $\stackrel{m}{q}$ & ल) & $F$ & $\frac{3}{7}$ & & ต̊ & 1 & $\ddot{m}$ & กิ & $\begin{array}{c}y \\
\infty\end{array}$ & & & & $\begin{array}{l}\infty \\
\substack{\infty \\
+\infty}\end{array}$ \\
\hline$\frac{\check{O}}{\infty}$ & 8 & 8 & 8 & 1 & 1 & $\stackrel{\infty}{\Xi}$ & 1 & $\begin{array}{l}\bar{m} \\
\\
\end{array}$ & $\begin{array}{l}\infty \\
8 \\
8 \\
\end{array}$ & 링 & $\begin{array}{l}\text { m. } \\
6 \\
0\end{array}$ & 항 & $\stackrel{\infty}{\Xi}$ & 1 & $\begin{array}{l}\bar{m} \\
\\
0\end{array}$ & 8 & 8 & $\begin{array}{l}8 \\
8 \\
8 \\
\end{array}$ & 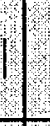 & & $\frac{8}{0}$ \\
\hline 宽 & 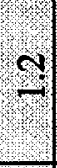 & $\because$ & त- & - & ? & $\tilde{n}$ & n? & $\tilde{n}$ & 3 & 3 & m & 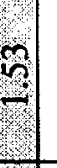 & ñ & $\tilde{n}$ & 1 & ㄱ. & $\stackrel{9}{-}$ & & & & ? \\
\hline 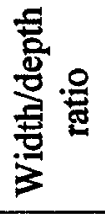 & $\infty$ & n: & त्र & m. & 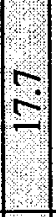 & $\stackrel{+}{\infty}$ & $\begin{array}{l}\stackrel{0}{9} \\
\text { ñ }\end{array}$ & $\stackrel{\sim}{\stackrel{\sim}{\Xi}}$ & $\stackrel{\infty}{=}$ & 8 & $=$ & के & $\stackrel{v}{\dddot{n}}$ & $\tilde{n}$ & 1 & 8 & $=$ & & & & $\bar{\infty}$ \\
\hline 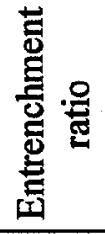 & $\stackrel{9}{-1}$ & $\stackrel{\infty}{\infty}$ & กิ & त & $\therefore$ & $n$ & กุ & 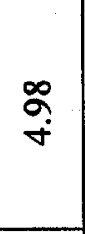 & ?ి & $\frac{m}{6}$ & 8 & $\forall$ & $\begin{array}{l}\nabla \\
\dot{m}\end{array}$ & $\begin{array}{l}\nabla \\
\dot{m}\end{array}$ & 1 & $\stackrel{\infty}{\infty}$ & $\infty$ & हे: & 2 & & nָ \\
\hline 苂 & ดे & $\begin{array}{l}5 \\
0 \\
0\end{array}$ & $\frac{\infty}{8}$ & ลे & 8 & ڤั & ईิ & $\stackrel{\infty}{\Xi}$ & 8 & क人 & $\begin{array}{l}\infty \\
\vdots \\
=\end{array}$ & ते & ڤ̊ & $\stackrel{5}{\infty}$ & $\stackrel{\infty}{\triangleq}$ & है & $\begin{array}{c}5 \\
\infty \\
0\end{array}$ & $\stackrel{\infty}{=}$ & रे। & & ڤ̊ \\
\hline 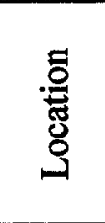 & 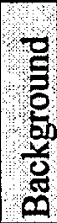 & 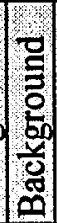 & 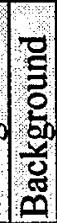 & 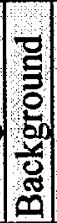 & 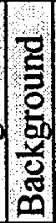 & 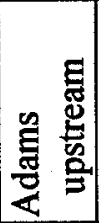 & 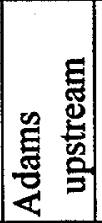 & 罚 & 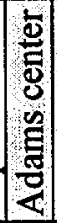 & 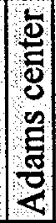 & 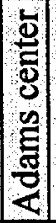 & 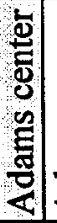 & 总 & 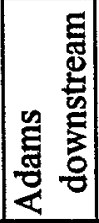 & 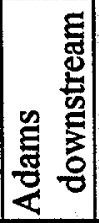 & $\begin{array}{l} \\
3 \\
3\end{array}$ & $\frac{N}{2}$ & $\sum^{N}$ & $\frac{1}{8}$ & & b \\
\hline
\end{tabular}


Table 3.2. (continued)

\begin{tabular}{|c|c|c|c|c|c|c|c|c|c|c|c|c|c|}
\hline Location & Date & $\begin{array}{c}\text { Entrenchment } \\
\text { ratio }\end{array}$ & $\underset{\text { ratio }}{\text { Width/depth }}$ & Sinuosity & Slope & $\begin{array}{l}\text { Riffle } \\
(\%)\end{array}$ & $\begin{array}{l}\text { Pool } \\
(\%)\end{array}$ & $D / 25$ & $\mathrm{D} / 50$ & $\mathrm{D} / 75$ & $\begin{array}{l}\text { Velocity } \\
(\mathrm{ft} / \mathrm{s})\end{array}$ & $\begin{array}{c}\text { Discharge } \\
\left(\mathrm{ft}^{3} / \mathrm{s}\right)\end{array}$ & Type $^{a}$ \\
\hline $\begin{array}{l}\text { D. S. Owl } \\
\text { Barn }\end{array}$ & $08 / 97$ & 1.26 & 29.79 & 1.5 & 0.0145 & 43.57 & 56.42 & Silt/clay & Gravel & Gravel & 0.48 & 1.58 & F4 \\
\hline $\begin{array}{l}\text { D. S. Owl } \\
\text { Barn }\end{array}$ & $11 / 98$ & 1.72 & 22.3 & 1.5 & - & - & - & Silt/clay & Silt/clay & Silt/clay & - & - & $\mathrm{B} 6^{\mathrm{c}}$ \\
\hline $\begin{array}{l}\text { D. S. Owl } \\
\text { Barn }\end{array}$ & $12 / 99$ & 1.92 & 24.7 & 1.5 & - & - & - & Silt/clay & Gravel & Gravel & - & - & $\mathrm{B} 4^{c}$ \\
\hline $\begin{array}{l}\text { D. S. Owl } \\
\text { Barn }\end{array}$ & $07 / 00$ & 1.91 & 22.28 & 1.5 & - & - & - & Sand & Gravel & Gravel & - & - & $\mathrm{B} 4^{c}$ \\
\hline Confluence & $10 / 96$ & 5.71 & 9.73 & 1.5 & 0.0131 & 46.27 & 53.72 & \multicolumn{3}{|c|}{ No graphs for data } & $\frac{1}{x-2}$ & $=$ & E6 \\
\hline Confluence & $08 / 97$ & 8.22 & 5.84 & 1.5 & 0.0130 & 29.05 & 70.95 & \begin{tabular}{|l|} 
Silt/clay \\
\end{tabular} & Gravel & Gravel & 118 & 19 & $\mathrm{E} 4$ \\
\hline Confluence & $09 / 98$ & 8.80 & 5.48 & 1.5 & 0.0126 & 30.60 & 69.40 & Silt/clay & Sand & Gravel & -2 & 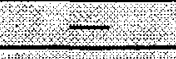 & E5 \\
\hline Confluence & $12 / 99$ & 7.9 & 5.5 & 1.5 & 0.0126 & - & 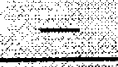 & Silt/clay & Sand & Gravel & $=$ & $=2$ & E-4 \\
\hline Confluence & $07 / 00$ & 8.6 & 4.9 & 1.5 & 0.0126 & $\rightarrow$ & $=$ & Sand & Gravel & Gravel & $\sqrt{y+2}$ & $s$ & $\mathrm{E}-4$ \\
\hline
\end{tabular}

Note: $-=$ no measurements made.

${ }^{a}$ Type $=$ Rosgen, D. L. 1994. A classification of natural rivers. CATENA. 22: 169-199.

${ }^{b}$ Graded for a F4b because entrenchment ratio is borderline between types. Called B4 based on professional judgment.

${ }^{c}$ Graded to B6c because entrenchment ratio is too high. The high ratio was caused by very high mass wasting at the cross section. Overall section is an F6. 
2. Width/depth ratio-The most important data from the cross-sectional measurements are the width/depth ratios. An increasing width/depth ratio indicates that the stream is unable to move its sediment load and/or that the banks are very unstable. The data demonstrate stable conditions at the background location and improving conditions at the confluence location. Data for the Adams locations show stability except for a very high number caused by 1997 fence construction at the upstream location. Although the width/depth ratios indicate stability, field notes indicate difficulty in picking the bankfull stage because of severe mass wasting on one bank and trampling of vegetation by livestock on the other. Quantitative evidence for these problems is discussed in Sect. 3.3. Both the MZ-2 and D. S. Owl Barn locations show an increasing width/depth ratio since the cross sections were established. At these locations, as at the Adams locations, severe mass wasting was observed.

3. Sinuosity - Sinuosity was measured from a topographic map. The value is used to classify the stream according to the scheme presented in Fig. 1.1. Actual field measurements would be required to determine whether there was a trend.

4. Slope-The stream slope is used to classify the stream according to the scheme presented in Fig. 1.1. A slope that steepens with time indicates incision and channelization. More data are needed to determine if there are any significant trends with respect to slope.

5. Riffle/pool percent-The percentage of stream length classified as riffle or pool is used to evaluate whether the stream is becoming wider and shallower. There is not an obvious trend in Table 3.2. However, the year-to-year variations are suggestive of an unstable system.

6. $\mathrm{D} / 25, \mathrm{D} / 50, \mathrm{D} / 75$ - These data are taken from the pebble count. The $\mathrm{D} / 50$ is the median particle moved by the stream and is used in the classification table in Fig. 1.1. Streams with a $\mathrm{D} / 50$ of sand or gravel are much more productive biologically than those with a silt and clay substrate because the latter prevent light penetration and air exchange. Data from the background site (Fig. 3.2) indicate that gravel is the natural D/50 for Montezuma Creek.

The pebble count also yields a determination of how the stream bottom varies year-by-year. An increasing accumulation of silt and clay indicates increased bank erosion and/or an altered flow regime. In 1996, the D/50 for the Adams center location was a gravel just as at the background location. However, in 1997 and 1998, the D/50 at the Adams center location became a silt/clay (Fig. 3.3). This change indicates that the gravels have become covered with fine sediment, an indication of a significant increase in sediment supply. In addition, although a silt/clay substrate was identified in both 1997 and 1998, field notes indicate that additional fine sediment had accumulated in 1998 such that the total depth of fine sediment was approximately 8 in.

The MZ-2 site had a silt-clay substrate during each survey (Fig. 3.4). Figure 3.4 shows data through 1998, but the 1999 and 2000 surveys indicated no change from 1998. Through 1998, the D. S. Owl Barn location showed the same effects as the Adams site in that the D/50 went successively from sand or gravel to silt-clay (Fig. 3.5). In 1999 and 2000, however, the pebble count for the D. S. Owl Barn site again has a D/50 of gravel with the graph's appearance much like the August 1997 data in Fig. 3.5. The confluence location, as at the background site, shows little change during the survey period (Fig. 3.6). The data for July 2000 at the confluence site are virtually identical to the 1998 data shown in Fig. 3.6. 

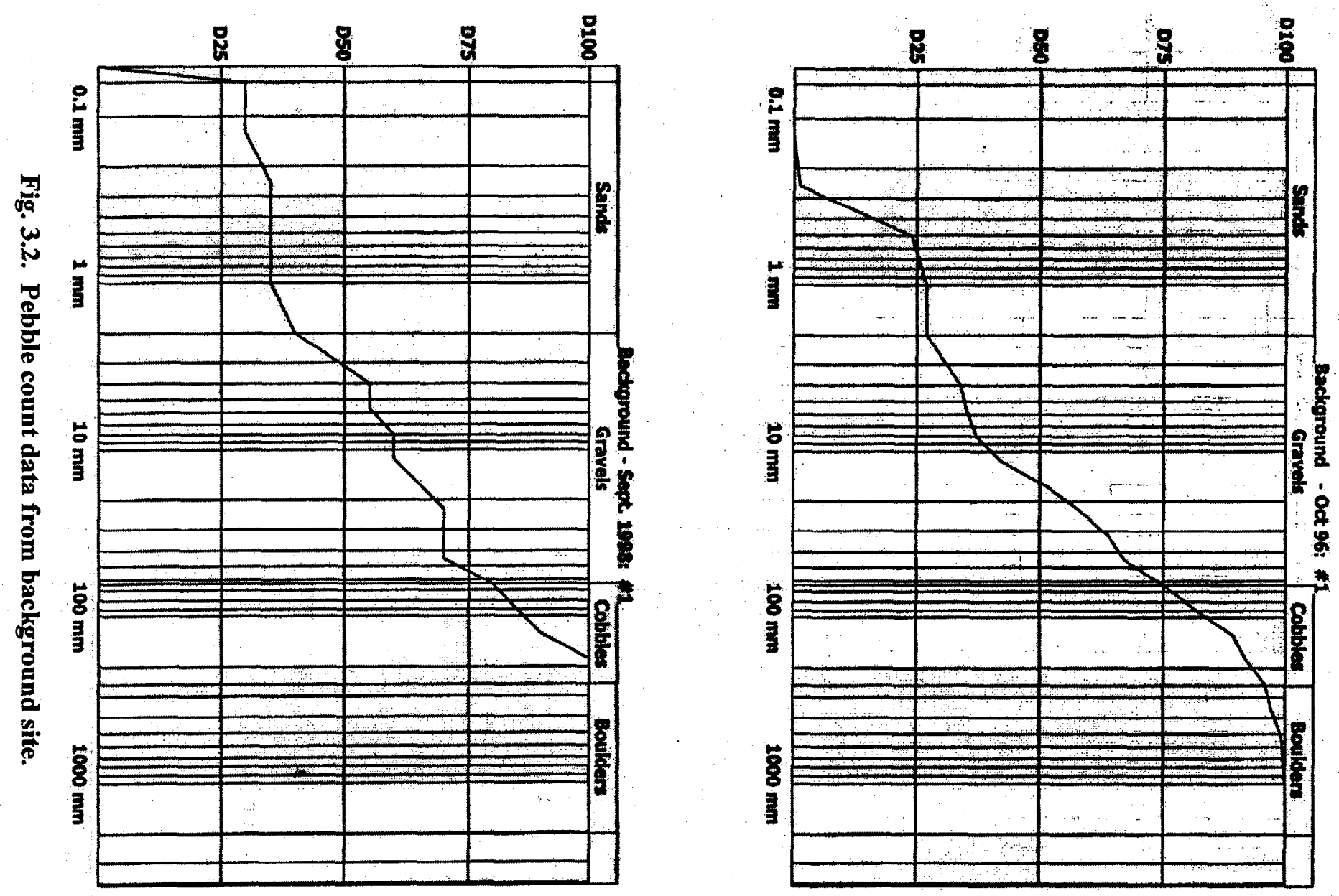

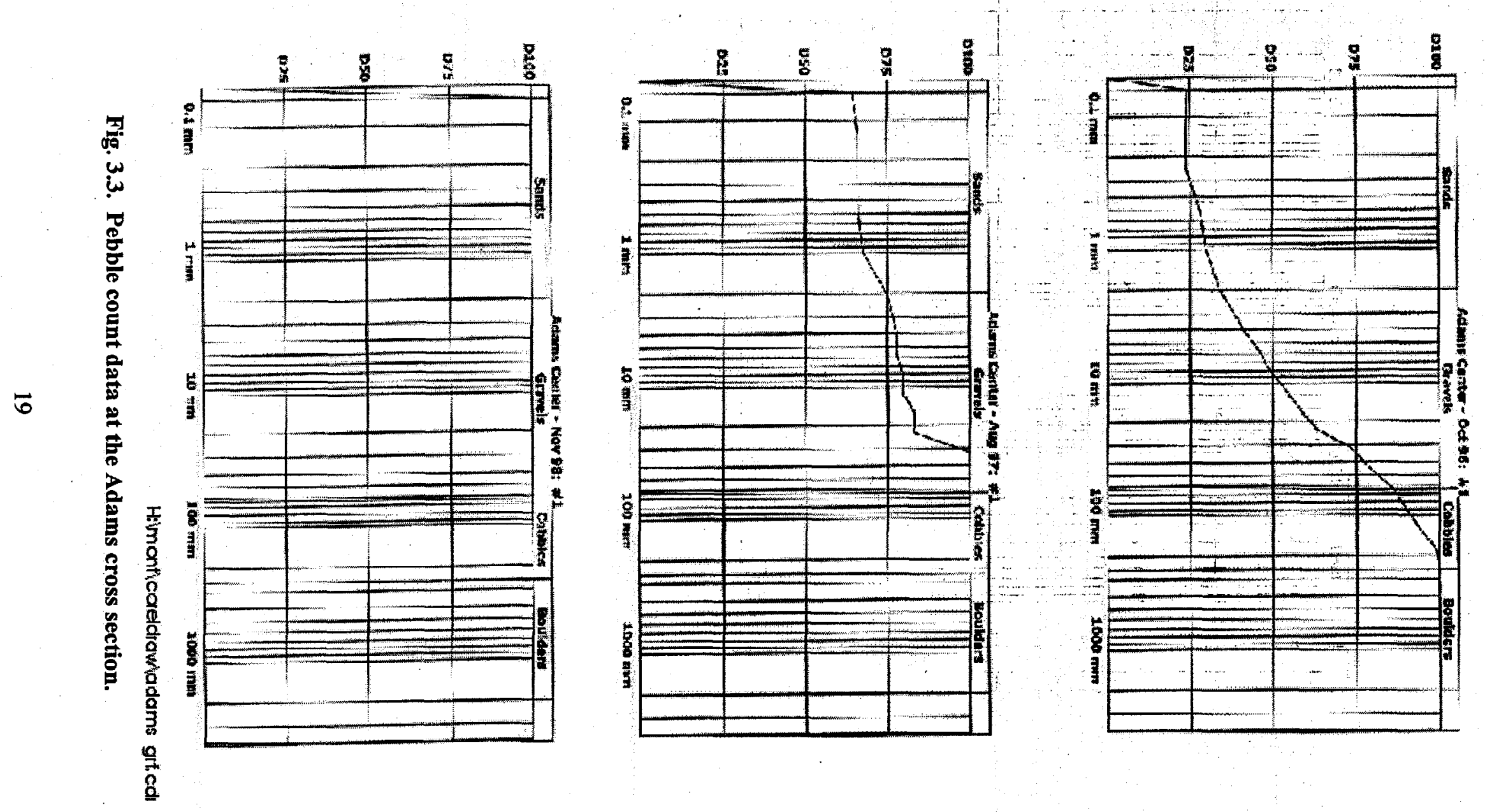

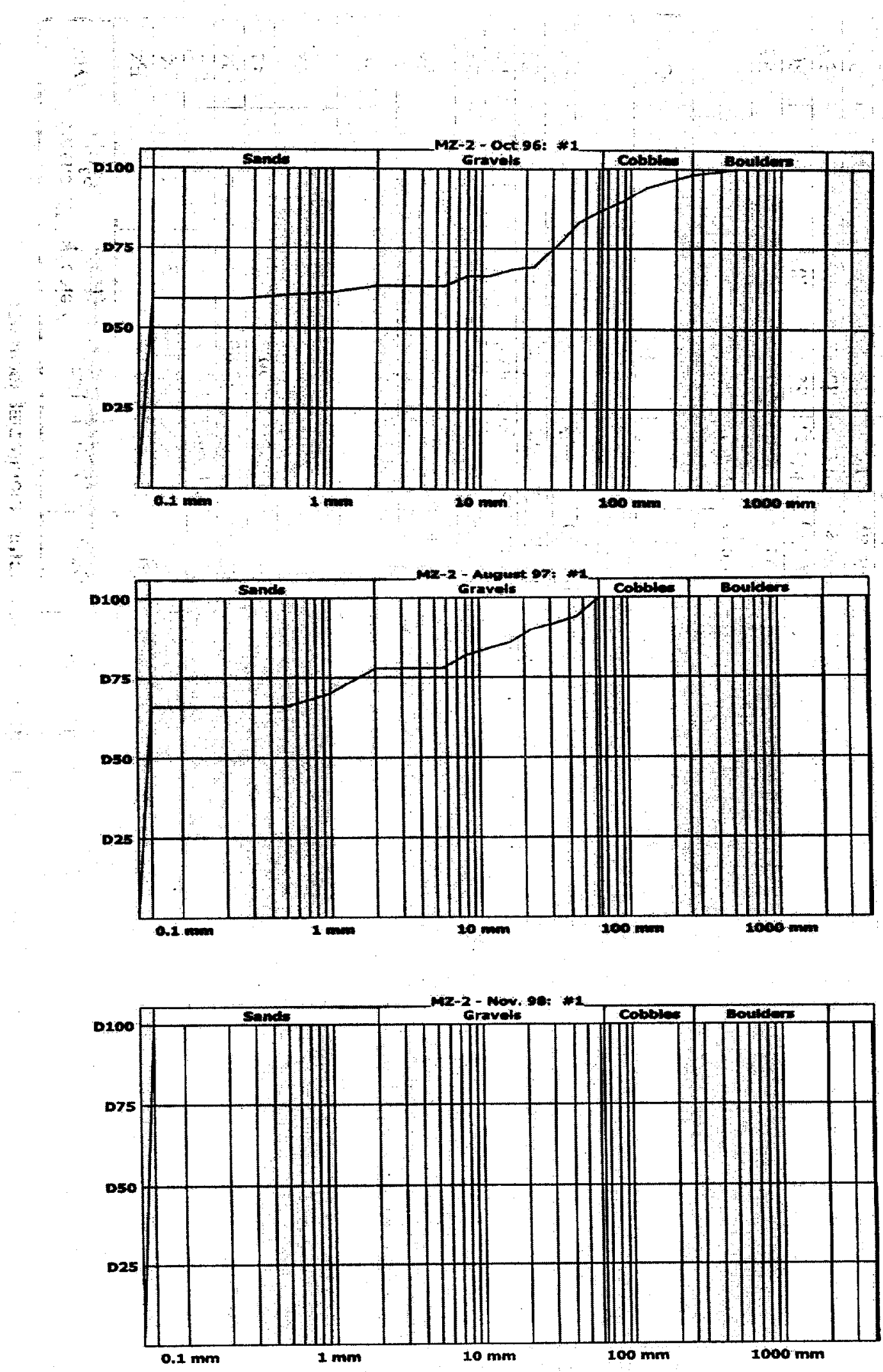

Fig. 3.4. Pebble count data at the MZ-2 cross section. 

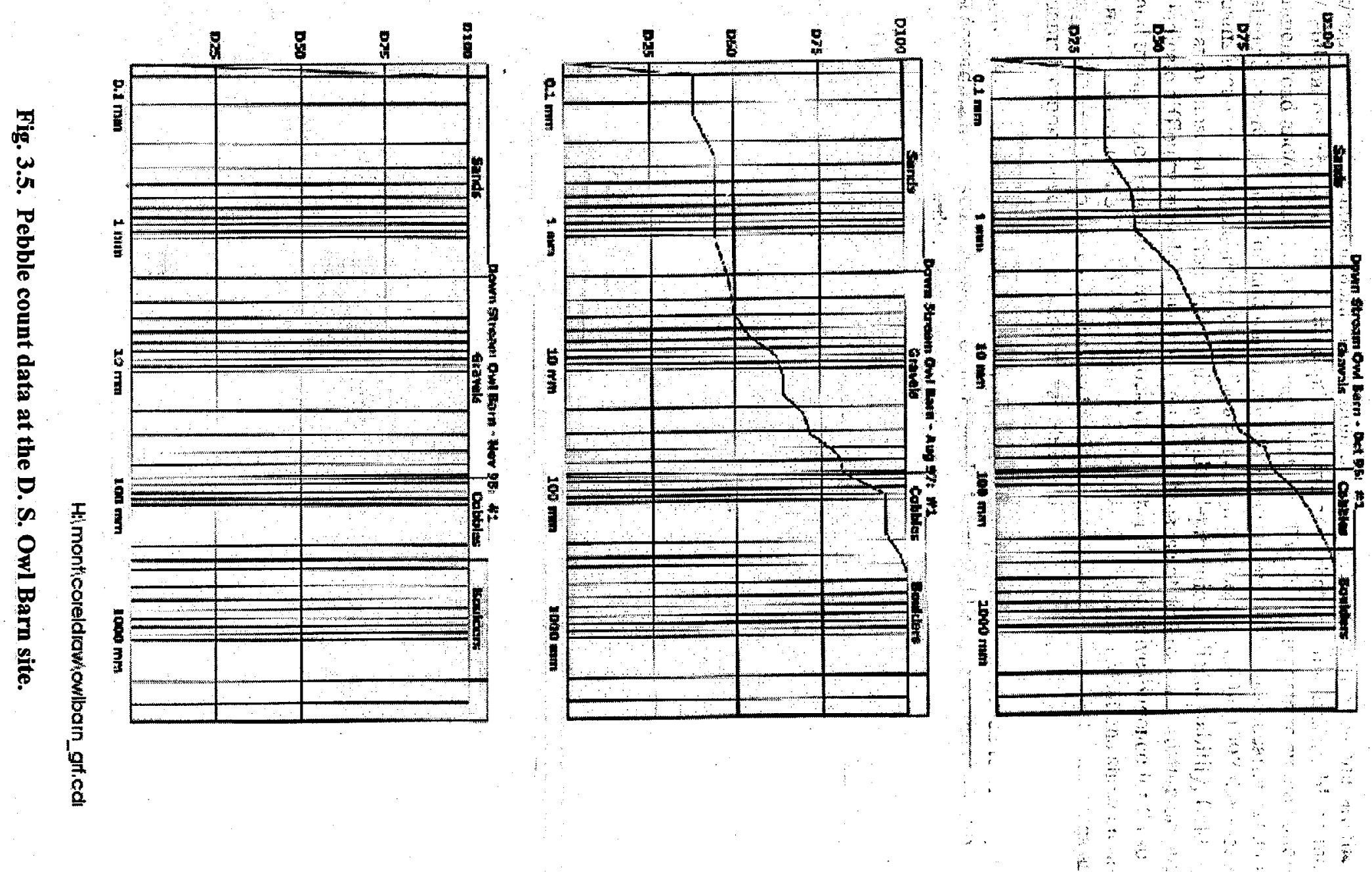

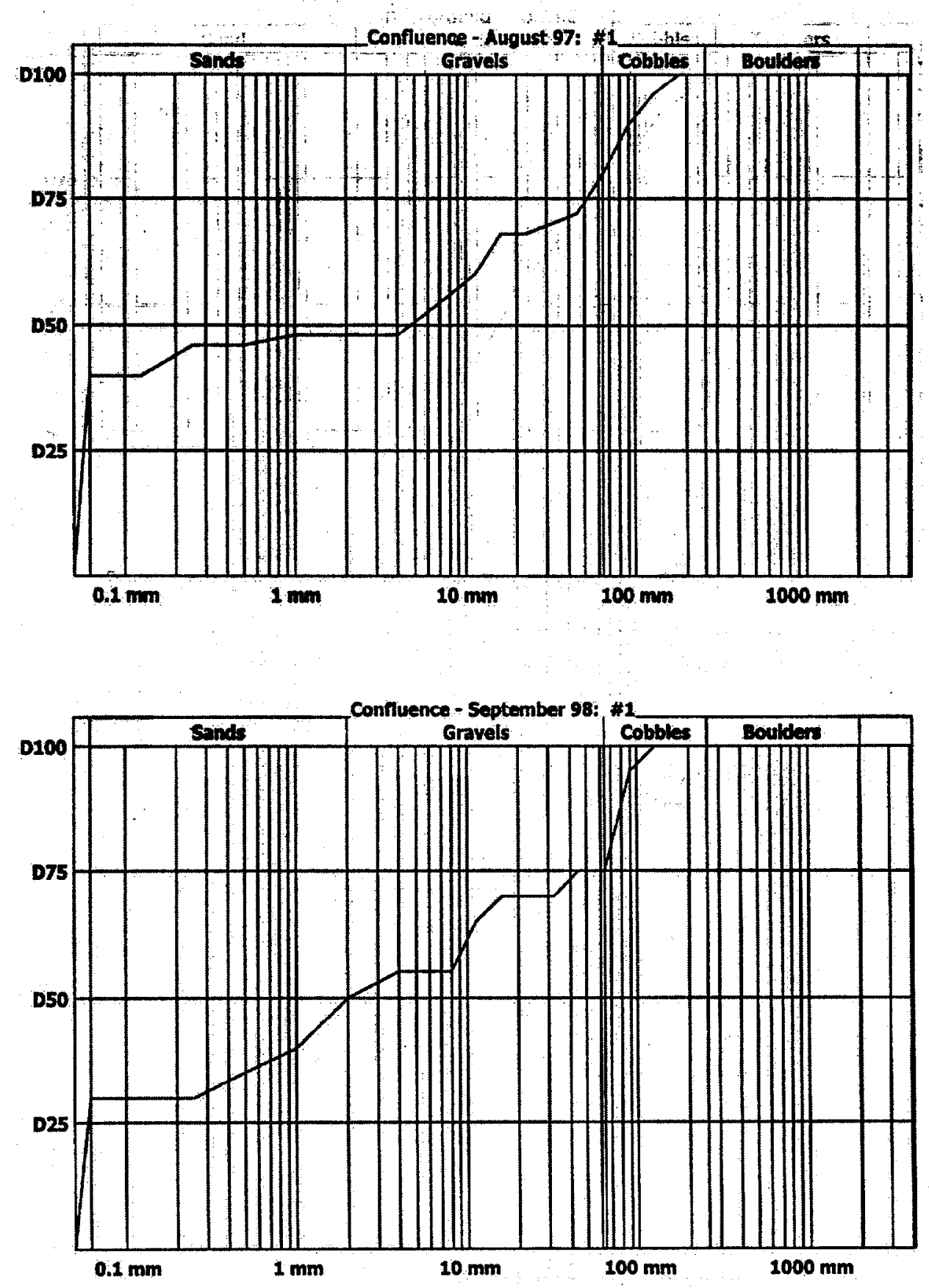

Fig. 3.6. Pebble count data at the confluence cross section. 


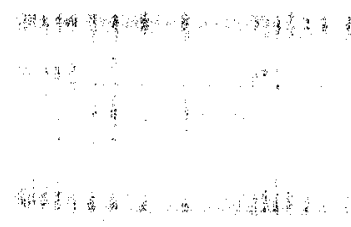

The $D / 75$ is used to estimate the largest particle moved at the bankfull stage. Again, the results show deterioration in strcam competence during the remediation period. For example, the $\mathrm{D} / 75$ at the Adams cross section, MZ-2, and D. S. Owl Barn all changed from gravel or sand to silt-clay during the course of these surveys. These data demonstrate that sediment supply was increased and flow competence decreased during 1997 and 1998 when remediation was at its peak. The Adams and MZ-2 sites have not recovered, but there may be a significant contribution of fine sediment from the land use at the Adams site.

7. Velocity/Discharge-Velocity and discharge measurements were made during the 1997 survey. The data indicate relatively good agreement between the background and confluence sites. However, the low readings for the other locations indicate that either the velocity measurements or the bankfull cross-sectional areas were incorrect. Either explanation is possible because velocity measurements are inherently error-prone when the water is very shallow, as at the locations where width/depth ratio is widest. Similarly, the cross-sectional area is very difficult to measure at highly impacted locations such as these.

8. Type-The data in Table 3.2 are collectively used to determine the geomorphic stream type using the scheme from Fig. 1.1. The data demonstrate that the background location is a B4, as compared to the confluence location, which is an E4 or E5. The B and E stream types are typical, natural stream types for the terrain through which Montezuma Creek flows. The background location is less entrenched and less sinuous with a somewhat higher slope, hence the B stream type. The confluence location is in a flat plain where more sinuosity and lower slope result in an E stream. The Adams, MZ-2, and D. S. Owl Barn locations all would be expected to be $\mathrm{E}$ streams based on the data from the confluence and the background locations. Instead, $\mathrm{C}$ and $\mathrm{F}$ classifications were usually found. As demonstrated by Rosgen (1994), when an $\mathrm{E}$ stream deteriorates, it initially may grade as a $\mathrm{C}$ before becoming an $\mathrm{F}$ (Fig. 3.7). An F-stream is a highly entrenched stream with unstable banks on both sides.

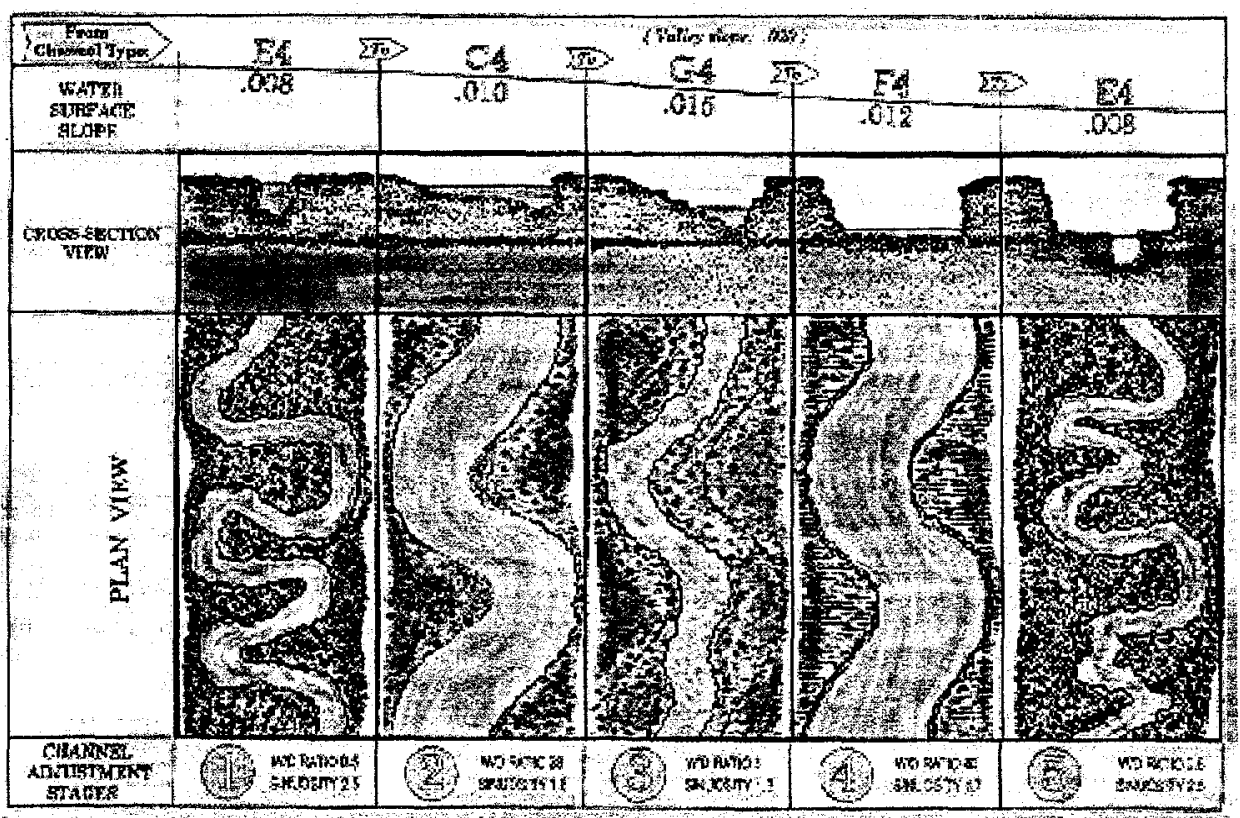

Fig. 3.7. Successive changes undergone by an impacted E stream (Rosgen 1994). 
In summary, data from the qualitative surveys and the physical measurements demonstrate that Montezuma Creek is in a degraded condition from the millsite at least as far as the D. S. Owl Barn location. Pebble count data demonstrate a deterioration in stream conditions from 1996 to 1998. No other measurements clearly indicate increasing degradation of the stream; however, several aspects of the qualitative survey are also suggestive of decreasing stream competence and productivity during remediation. Finally, the pebble count data also demonstrate some postremediation improvement as silt-clay accumulation was less at some sites. 


\section{BANK EROSION MEASUREMENTS}

Bank erosion was measured with bank pins that consist of rebar hammered into the banks. The bar is driven until the end is flush with the bank. If the banks erode, then some of the bar is exposed. The exposed rebar, therefore, shows how much the channel has widened over the measurement period.

\subsection{CHANGES FROM 1996 TO 1997}

\subsubsection{Adams Cross Section}

Figure 4.1 shows that $16 \mathrm{~cm}$ ( $6.3 \mathrm{in}$.) of bank collapsed at the Adam's downstream cross section. The exposed bank at this location was approximately $100 \mathrm{ft}$ long and $6 \mathrm{ft}$ high. Thus, the sediment produced in one year from this section was approximately $300 \mathrm{ft}^{3}$ ( 23.4 tons). The center cross section, which was on the south bank, showed a loss of $12 \mathrm{~cm}(4.7 \mathrm{in}$.$) ; thus, the land owner$ lost a section of pasture approximately $1 \mathrm{ft}$ by $100 \mathrm{ft}$ or $100 \mathrm{ft}^{2}$ from this small section of stream in 1 year.

Based on the significant mass wasting and associated changes in the channel, another bank pin was installed downstream of both the center and downstream cross sections.

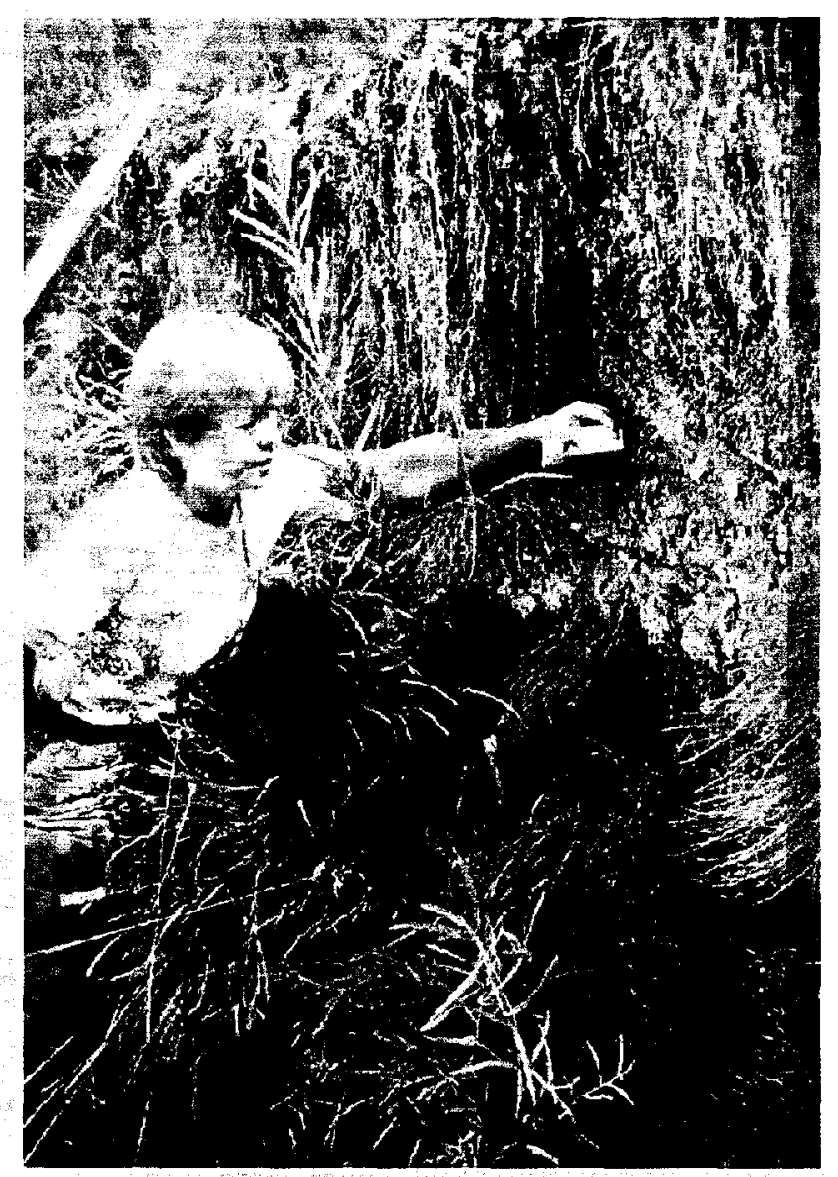

Fig. 4.1. Bank pin showing erosional loss at the Adam's cross section. 


\subsubsection{MZ-2 Cross Section}

Mass wasting occurred at this location (Fig. 4.2). However, the bank pin was positioned too low on the banks and was covered by sediment. Thus, it was not possible to estimate the tons of sediment lost. Another bank pin was installed downstream of the cross section to obtain future measurements.

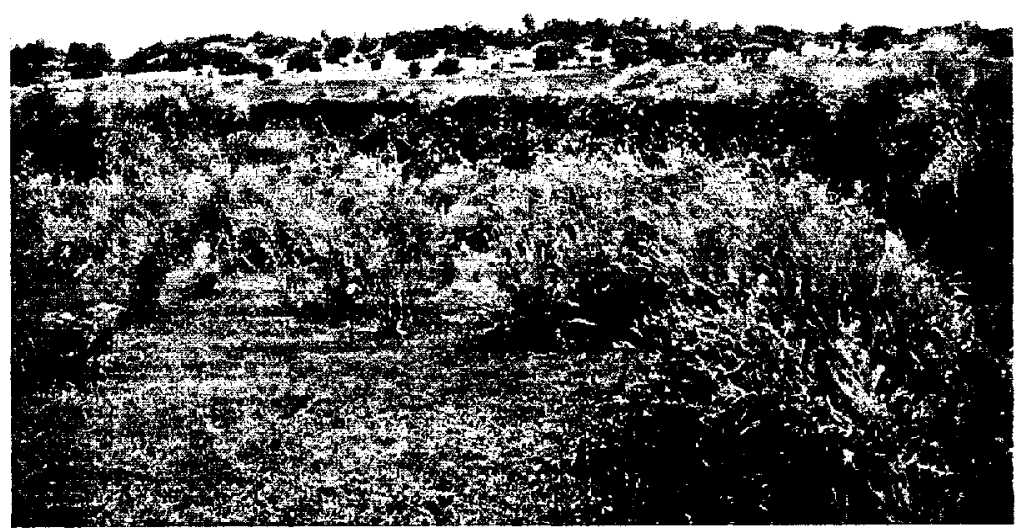

Fig. 4.2. Extensive bare stream banks at the MZ-2 cross section.

\subsubsection{S. Owl Barn Cross Section}

Figure 4.3 shows that $18 \mathrm{~cm}$ ( 7 in.) of sediment was removed at the D. S. Owl Barn location (Fig. 4.4). Also, the exposed cutbank is longer-approximately $200 \mathrm{ft}$ with banks $4 \mathrm{ft}$ high. Thus, the sediment produced in 1 year from this section was approximately $467 \mathrm{ft}^{3}$ (36 tons).

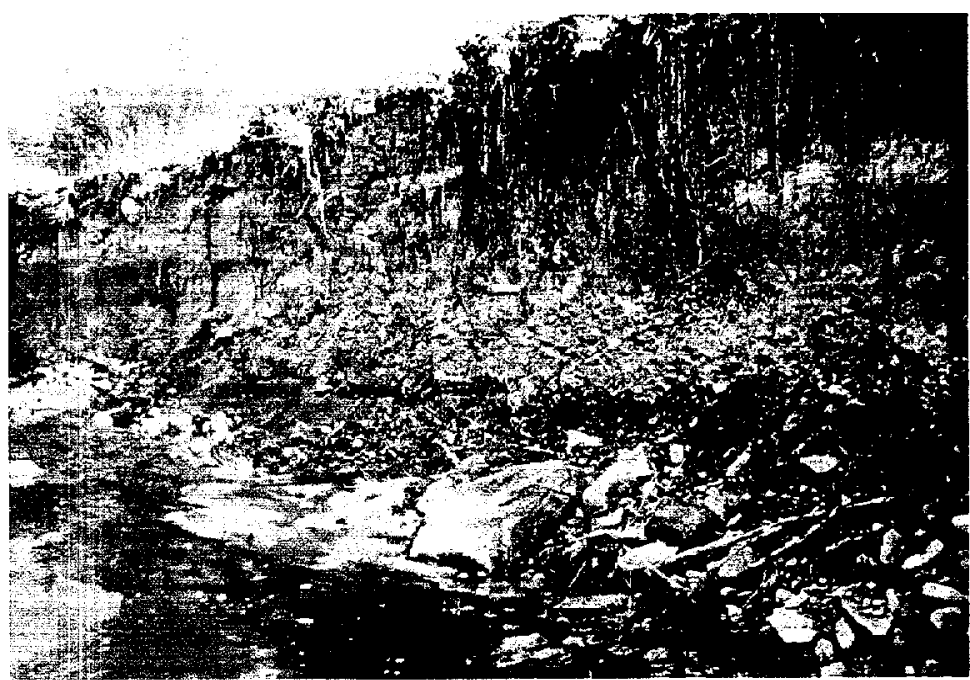

Fig. 4.3. Bank pin showing sediment removed at the D. S. Owl Barn location. 


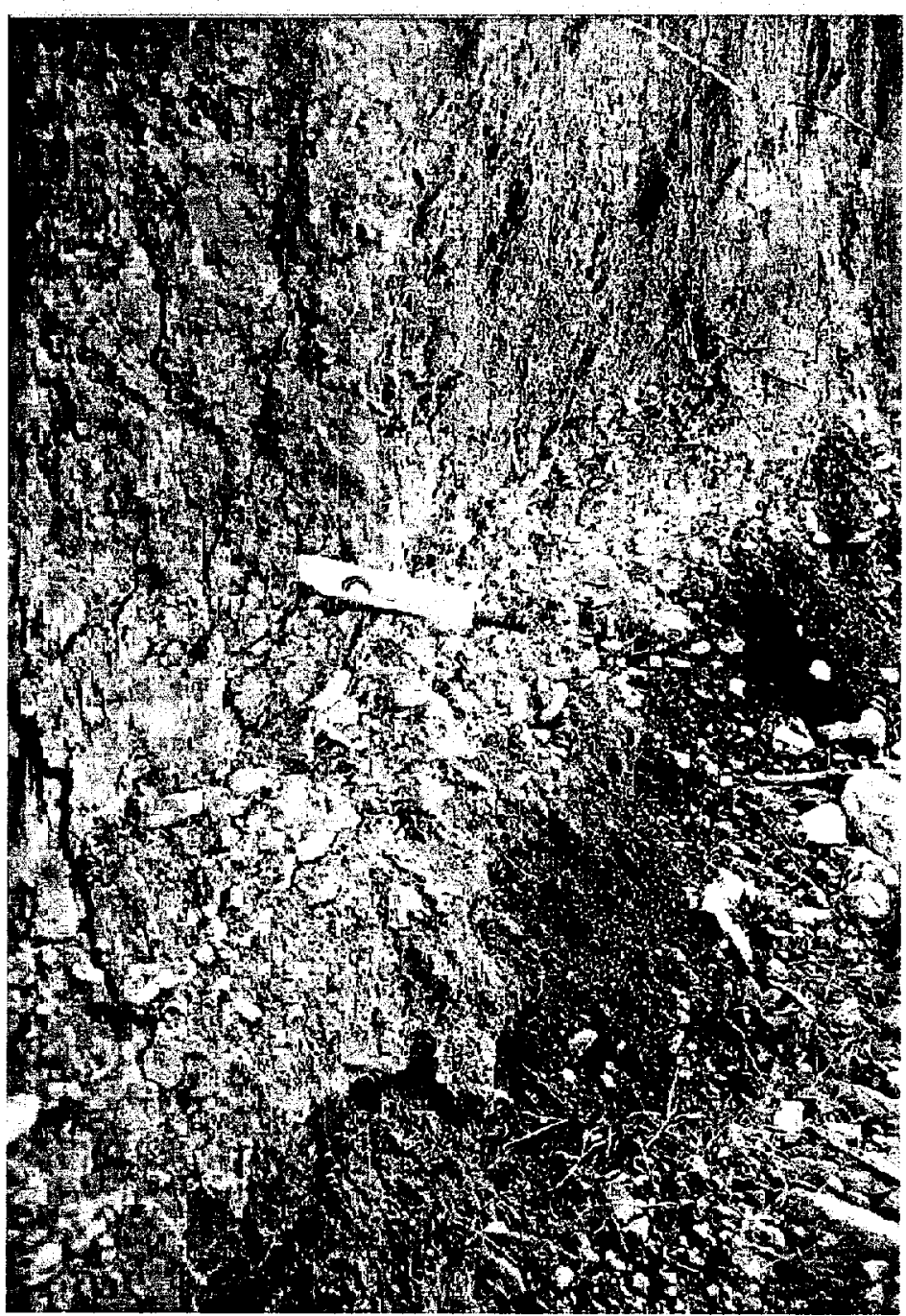

Fig. 4.4. Exposed cutbank at the D. S. Owl Barn cross section.

\subsubsection{Confluence Cross Section}

Locations show significant mass wasting throughout most of Montezuma's Creek's course toward Vega Creek. However, at distances greater from the millsite, the erosion is not so severe. The bank pin for the location just above the confluence with Vega Creek had only $2.5 \mathrm{~cm}(1 \mathrm{in}$.) of pin exposed (Fig. 4.5). In addition, the bank is only $3 \mathrm{ft}$ high and $50 \mathrm{ft}$ long (Fig 4.6). Thus, the erosion loss here is less than $15 \mathrm{ft}^{3}$ (1.2 tons).

\subsection{CHANGES FROM 1997 TO 1998}

\subsubsection{Adams Cross Section}

In November 1998, the bank pin at the center cross section was exposed $18 \mathrm{~cm}$ with a bank height of $4.5 \mathrm{ft}$ and a width of $196 \mathrm{ft}$. In 1997 , a second pin had been installed $18.3 \mathrm{ft}$ downgradient of the first. It also had $18 \mathrm{~cm}$ exposed, demonstrating that the bank had collapsed uniformly in the area. The erosion loss in this section, therefore, is $520 \mathrm{ft}^{3}$ (40 tons). 


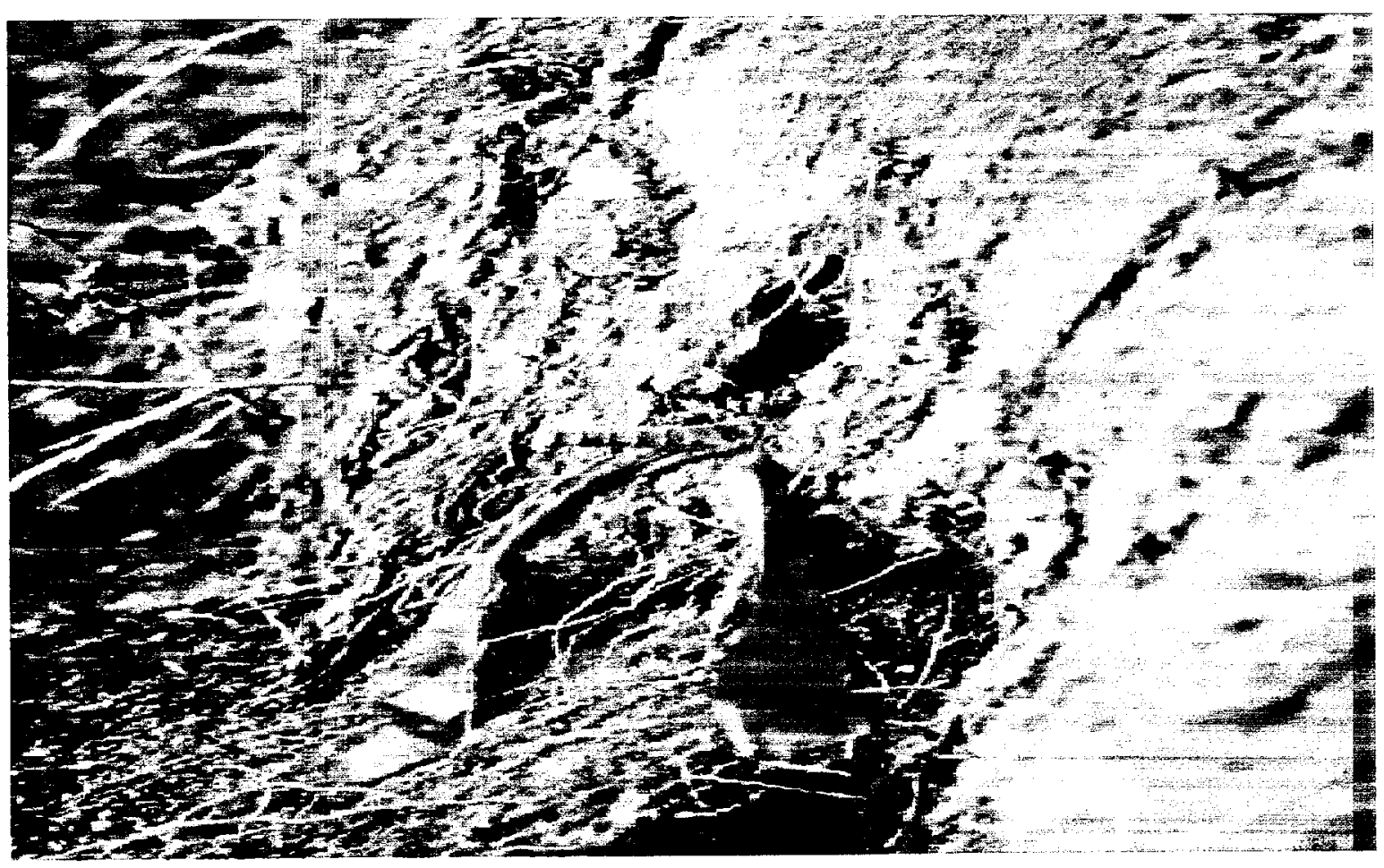

Fig. 4.5. Bank pin exposed at the confluence cross section.

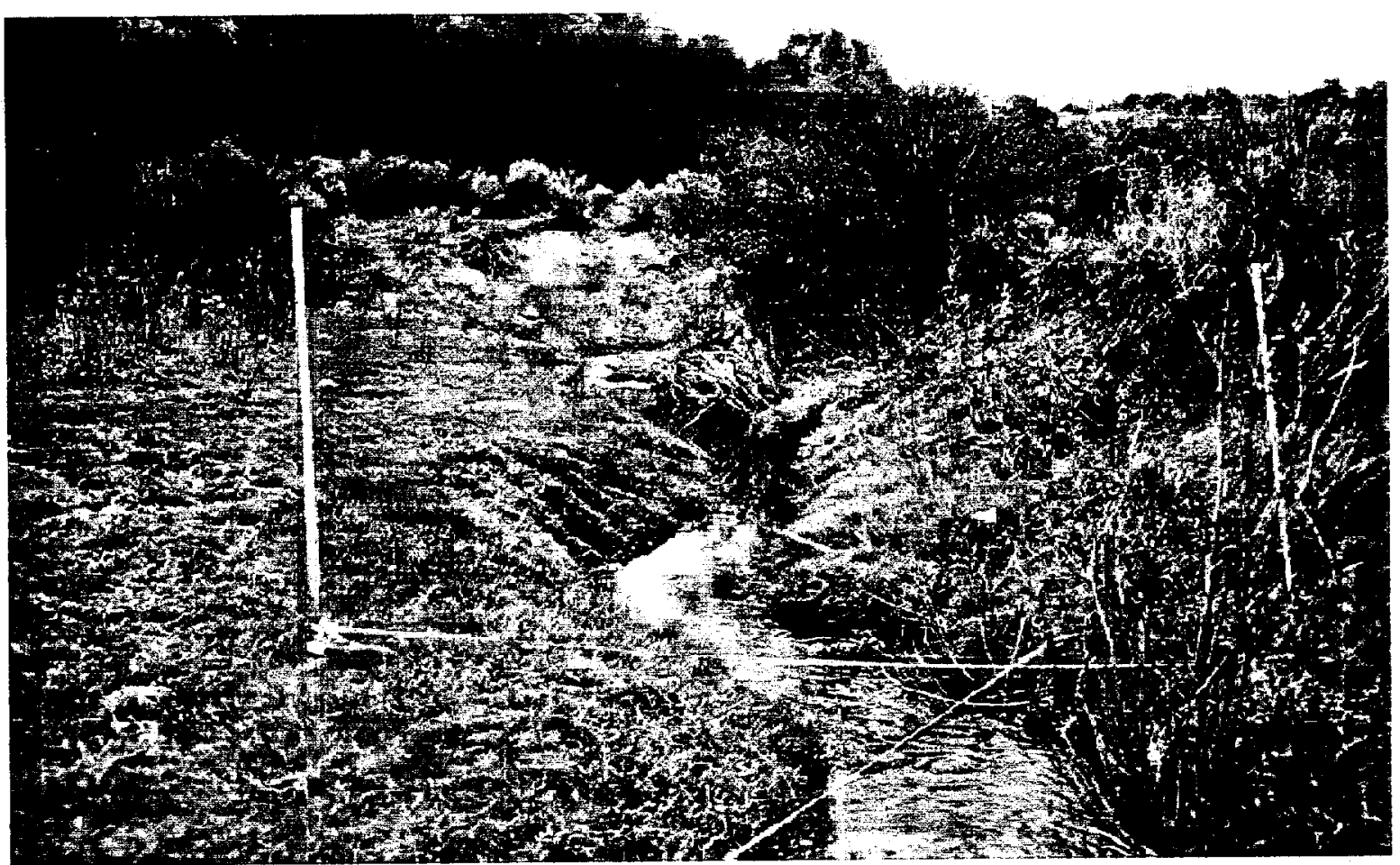

Fig. 4.6. Confluence cross section streambanks. 
At the downstream Adams cross section, the pin was exposed $6 \mathrm{~cm}$. Another pin, installed in 1997, was located $5.4 \mathrm{ft}$ further downstream and had $14 \mathrm{~cm}$ exposed. The latter pin was installed because the previous mass wasting had altered the channel such that the force of the current on the bend was shifted several feet downstream. The bank height in this area was $5 \mathrm{ft}$ with $75 \mathrm{ft}$ of collapsed bank. The 14-cm loss represented most of the collapsed bank. The erosion loss in this section, therefore, is $172 \mathrm{ft}^{3}$ (13 tons).

\subsubsection{MZ-2 Cross Section}

As noted above, a second bank pin was installed $18.3 \mathrm{ft}$ downstream from the $\mathrm{MZ}-2$ cross section. In September of 1998 , this pin was exposed $9.7 \mathrm{~cm}$. The average bank height in the area was estimated at $3 \mathrm{ft}$, and the length of collapsed bank was estimated at $135 \mathrm{ft}$. The erosion loss in this section, therefore, is $129 \mathrm{ft}^{3}$ (10 tons).

\subsubsection{S. Owl Barn Cross Section}

In September 1998, the bank pin at this cross section was exposed $60 \mathrm{~cm}$ with banks $4 \mathrm{ft}$ high. The total length of collapsed bank was $110 \mathrm{ft}$. A new bank pin was also installed $41 \mathrm{ft}$ downstream from the cross section. The erosion loss in this section, therefore, is $866 \mathrm{ft}^{3}$ (67 tons).

\subsubsection{Confluence Cross Section}

In September 1998, the bank pin at this cross section was exposed $4.5 \mathrm{~cm}$. The bank height was $2.5 \mathrm{ft}$, and the affected area was $88 \mathrm{ft}$ long. The erosion loss in this section, therefore, is $32 \mathrm{ft}^{\prime}$ (2.5 tons).

\subsection{CHANGES FROM 1998 TO 1999}

\subsubsection{Adams Cross Section}

In December 1999, the bank pin at the center cross section was exposed $18 \mathrm{~cm}$ with a bank height of $4.5 \mathrm{ft}$ and a width of $196 \mathrm{ft}$ (see Sect. 4.2.1). In 1997, a second pin had been installed $18.3 \mathrm{ft}$ downgradient of the first. In December 1999, the first pin was missing, apparently having been eroded away. The second of these pins was exposed $18 \mathrm{~cm}$. Assuming the same 196- $f$ length with $18 \mathrm{~cm}$ of erosion, the total soil loss was $686 \mathrm{ft}^{3}$ (54 tons).

At the downstream Adams cross section, the bank pin was missing. Another pin, installed in 1997, was located $5.4 \mathrm{ft}$ further downstream and had $18 \mathrm{~cm}$ exposed. The latter pin was installed because the previous mass wasting had altered the channel such that the force of the current on the bend was shifted several feet downstream. The bank height in this area was $6 \mathrm{ft}$ with $75 \mathrm{ft}$ of collapsed bank. The 18-cm loss represented most of the collapsed bank. The erosion loss in this section, therefore, is $262 \mathrm{ft}^{3}$ ( 21 tons).

After this survey, the remaining bank pins were removed, and the cross sections were abandoned. This action was taken because the landowner is grazing so many livestock in the area that it is completely denuded of vegetation and not representative of the effects of DOE's remediation at the Monticello millsite.

\subsubsection{MZ-2 Cross Section}

A pin was installed a few feet upstream of the cross section. It was exposed approximately $2 \mathrm{~cm}$. It was unclear whether there was erosion at this location, therefore, no loss was estimated. 
The downstream pin was exposed $10 \mathrm{~cm}$. Some of the banks in this area, however, are now well protected by vegetation. Thus, three separate areas with collapsed banks were measured. These were $5 \mathrm{ft}$ by $15 \mathrm{ft}, 3 \mathrm{ft}$ by $62 \mathrm{ft}$ and $3 \mathrm{ft}$ by $30 \mathrm{ft}$. Assuming that the $10 \mathrm{~cm}$ applies to these areas, the total soil loss was $116 \mathrm{ft}^{3}$ (9 tons).

\subsubsection{S. Owl Barn Cross Section}

In December 1999, the bank pin at the cross section was not exposed. In the past, significant exposure had been observed at this pin. However, so much sediment has fallen that the stream is now diverted from this bank. For that reason, additional pins were installed downgradient from the cross section. The bank pin $23 \mathrm{ft}$ downstream of this cross section was exposed slightly less than $25 \mathrm{~cm}$ with banks $5.5 \mathrm{ft}$ high. The new bank pin that was installed $41 \mathrm{ft}$ downstream from the cross section in 1999 was also exposed $25 \mathrm{~cm}$. The length of the collapsed section was $66 \mathrm{ft}$. The erosion loss in this section, therefore, is $302 \mathrm{ft}^{3}$ ( 23.4 tons).

\subsubsection{Confluence Cross Section}

In December 1999, the bank pin at this cross section was exposed $6.4 \mathrm{~cm}$. The bank height was $2.5 \mathrm{ft}$ and the affected area was $80 \mathrm{ft}$ long. The erosion loss in this section, therefore, is $42 \mathrm{ft}^{3}$ (3.3 tons).

\subsection{CHANGES FROM 1999 TO 2000}

\subsubsection{Adams Cross Section}

As noted above, the bank pins were removed in 1999. The landowner was grazing a large number of elk in the area. The elk had essentially removed all of the vegetation. Bank recession was extreme and was caused primarily by the livestock.

\subsubsection{MZ-2 Cross Section}

The bank pins were not found by the field crew. At the cross section, it is likely that vegetation and mass wasting have covered the pins. At the downstream location, it appears that the pin may have fallen into the stream (Fig. 3.1). Note, however, that the area is better vegetated than in the past. Hence, the overall sediment loss at this cross section is less than in previous years.

\subsubsection{S. Owl Barn Cross Section}

At this location, only one bank pin was found, and it was exposed $6.2 \mathrm{~cm}$. Apparently the other bank pins had been removed by others. The length of the exposed section was approximately $70 \mathrm{ft}$ with banks $5.5 \mathrm{ft}$ high. Thus, the volume of soil lost was $78 \mathrm{ft}^{3}$ ( 6 tons).

\subsubsection{Confluence Cross Section}

The bank pin was not exposed in 2000 , indicating no measurable erosion loss.

\subsection{BANK EROSION SUMMARY}

Soil erosion from the cross sections studied (except for MZ-2) produced 60 tons of sediment in 1997. In 1998, the measured loss from the three cross sections was 130 tons. In 1999, the 
measured loss was approximately 110 tons. Based on the lower losses at the confluence and the D. S. Owl Barn site, overall erosion losses in 2000 were much less than during the years when the peak remediation occurred. No losses were assumed from the background location during the project period (Table 3.3 ).

Based on the topographic map, the estimated stream length from the Adams cross section to the D. S. Owl Barn section is $15,500 \mathrm{ft}$. The length of stream for which there are exposed vertical cutbanks was estimated by the project team as $40 \%$ or $12,400 \mathrm{ft}$ (based on $31,000 \mathrm{ft}$ of bank length). The average loss per foot of stream length with an exposed bank was 0.2 tons/ft in 1997 , 0.265 tons/ft in 1998, and 0.22 tons/ft in 1999. Hence, the estimated loss in this stretch of the stream was 2480 tons in 1997,3290 tons in 1998 , and 2700 tons in 1999 . Thus, the landowners are losing a portion of their acreage as well as pasture or cropland.

Table 3.3. Tons of sediment lost per cross section per year based on measurements with bank pins

\begin{tabular}{lcccc}
\hline \multicolumn{1}{c}{ Location } & $1996-1997$ & $1997-1998$ & $1998-1999$ & $1999-2000$ \\
\hline Adams & 24 & 53 & 75 & Not measured \\
MZ-2 & Bank pin buried & 10 & 9 & Bank pin not found \\
& with sediment & & & \\
D. S. Owl Barn & 36 & 67 & 24 & 6 \\
Above confluence & 1.2 & 2.5 & 3.3 & 0 \\
\hline
\end{tabular}




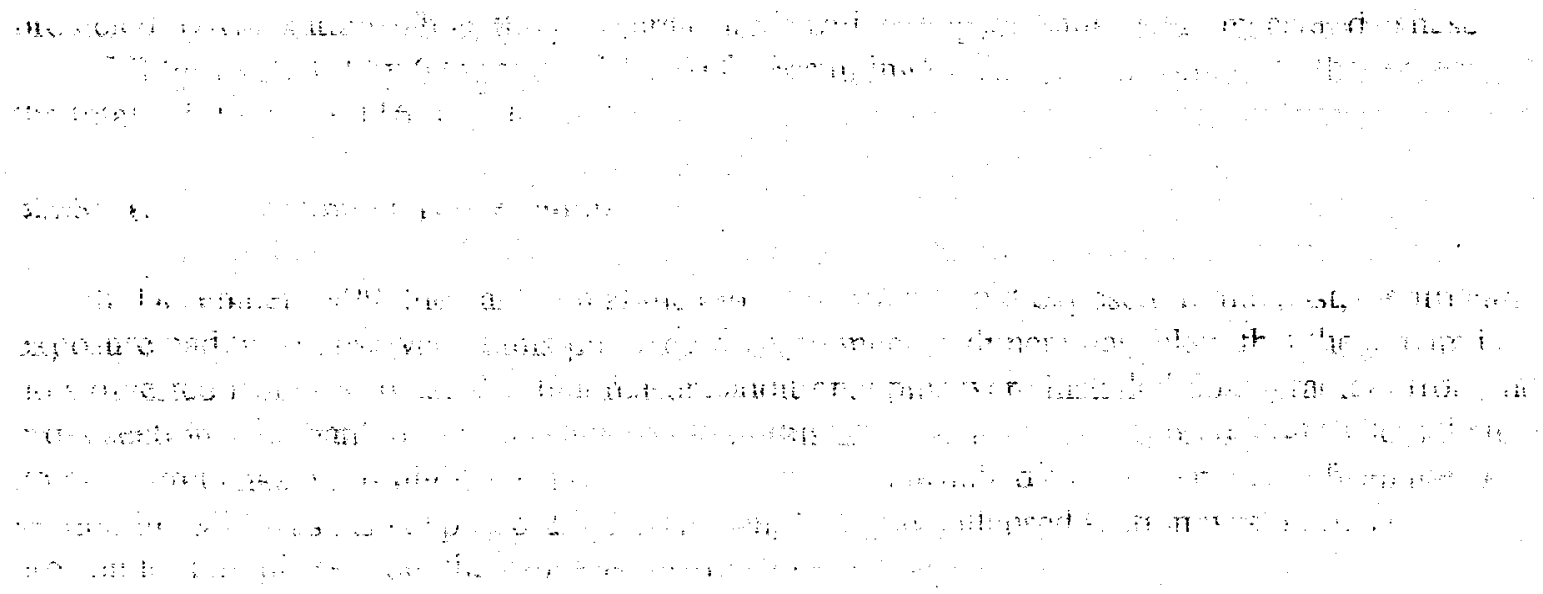




\section{EFFECTS OF REMEDIAL ACTIVITIES}

Work at the millsite and within Montezuma Creek employed BMPs to control sediment. However, as shown in Figs. 5.1, 5.2, and 1.3, these practices were not successful. The quantitative proof that remedial activities have affected the creek is provided by the pebble counts and the increase in erosion when remedial activities were at their maximum. The change in substrate from gravel to silt-clay indicates that the sediment supply increased dramatically.

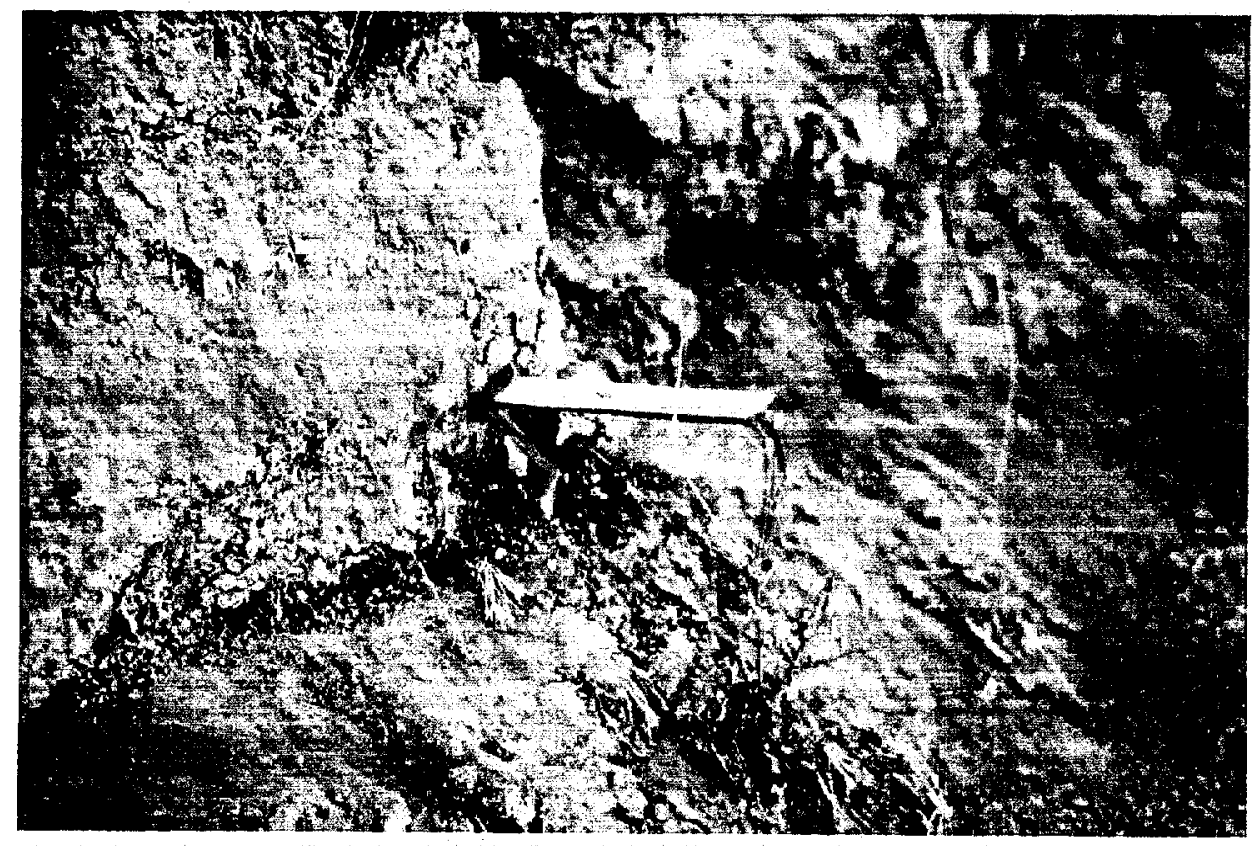

Fig. 5.1. Exposed bank pin showing effects of remedial activities.

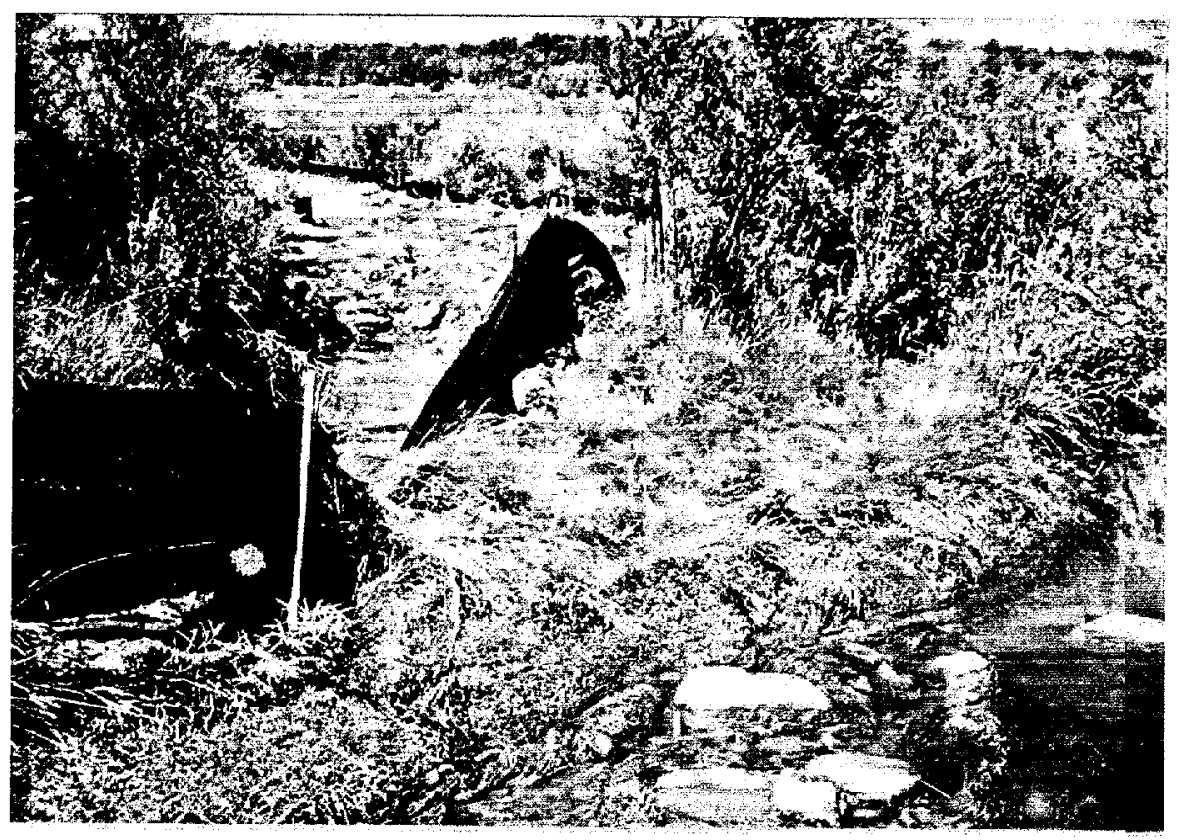

Fig. 5.2. Collapsed silt fence in Montezuma Creek during remedial activities. 
Although an officially recognized BMP, it is becoming widely recognized that silt fences do not work (Kasperson 2000, Kaufman 2000). For example, the following two quotes from Kasperson (2000) are from contractors who said they commonly use silt fences:

1. "It looks nice until it rains. Invariably, if you get a big heavy rain, it's gonna wash out and you're gonna get to go replace it."

2. "Ninety-five percent of the time silt fence is improperly installed or tipped over."

It is evident that contractors either do not follow BMP recommendations, and/or the law is not being enforced (Kaufman 2000). This scope of this problem, however, is nationwide. For example, 30 construction sites were evaluated in Illinois. Of these, only four exhibited marginally acceptable practices for erosion and sediment control (Kaufman 2000).

Similar to the BMPs for sediment control, DOE contractors employed conventional engineering practices when relocating Montezuma Creek. As shown in Fig. 1.2, the redesigned creek was placed in a straight, trapezoidal channel. This new channel is an " $F$ " or " $G$ " in the geomorphic classification system (Fig. 1.1). Both " $F$ " and " $G$ " channels are inherently unstable because they lack floodplains. Thus, high flows provide increasing stress to the banks, leading to erosion and increased maintenance. Such a trapezoidal stream also provides little in terms of aquatic habitat.

\subsection{AGRICULTURAL EFFECTS}

This project was inadequate for separating the effects of agricultural practices from those of the remedial activities. Much of the area is overgrazed as evidenced by the hard-packed soil, trampled vegetation, trampled creek channel, and evidence of piping along the banks. Furthermore, vegetation that might protect the banks from erosion has been removed in many locations (Fig. 4.2). Thus, agricultural impacts may be as significant or even more significant than the remedial activities with respect to degradation of the creek. The agricultural activities also inhibit postremediation natural restoration.

\subsection{COSTS}

One criticism of the geomorphic approach is a perceived high cost. However, a well-designed channel will require very little maintenance. Overall costs, when considering the future will always be less, especially if any value is given to the improvements in the functioning of the entire riparian system. Moreover, the overall costs of the present approach are also very high. Finally, in North Carolina, urban erosion and sediment control requirements were not particularly burdensome to the development industry (adding about 4\%); thus, the overall value to society is much greater than the cost of not being careful with development. Approximately six billion tons of soil erode from the nation's lands each year. Clark et al. (1985) and Colacicco et al. (1989) estimate that the sediment and sediment-related pollution cause $\$ 3.7$ to $\$ 14$ billion in damages each year in the United States, including loss of farm productivity. Sediment loads from construction projects can be 2000 times those from wooded land, 200 times greater than pasture and 10 to 20 times greater than cultivated land (Paterson et al. 1993). 


\section{CONCLUSIONS AND RECOMMENDATIONS}

The data acquired in this project demonstrate that remediation at the millsite increased erosion and sedimentation in Montezuma Creek. The data also indicate, however, that some recovery occurred once the soil-removal activities ceased. The data further demonstrate that agricultural practices are limiting improvement in stream conditions.

It is recommended that DOE not rely on rote application of BMPs for sediment control and stream routing. A review of appropriate erosion and sediment control methods is beyond the scope of this report, but many available approaches would have prevented the damage to the downstream environment described in this report. Although regulatory agencies are required to accept BMPs, there is ample recognition in the engineering and construction community that the practices are usually ineffective or provide only temporary benefit. The International Erosion Control Association or the National Resource Conservation Service has materials that can be used to design effective projects that take into account geomorphic principles and provide significant advantages over conventional engineering practices (NRCS 1998). 
\|\| 


\section{REFERENCES}

Clark, E. H., J. A. Haverkamp, and D. Chapman. 1985. Eroding Soils: The Off-Farm Impacts. The Conservation Foundation, Washington, D.C.

Colacicco, D., T. Osborn, and K. Alt. 1989. "Economic damage from soil erosion." J. Soil and Water Conservation, 44(1): 35-39.

DOE. 1998. Monticello Mill Tailings Site, Operable Unit III Remedial Investigation. GJO-97-6/GJO-MRAP-37. U.S. Department of Energy, Grand Junction, Colorado.

Ferguson, B. K. 1991. "Urban stream reclamation." J. Soil and Water Conservation, 46(5): 324-328.

Hey, D. L., et al. 1989. "Restoration of riverine wetlands: The Des Plaines River Wetlands Demonstration Project." In Ecological Engineering: An Introduction to Ecotechnology, W. J. Mitsch and S. E. Jorgensen, eds., John Wiley and Sons, New York.

IECA. 1998. "Who needs a BMP that doesn't work?" International Erosion Control Association, Erosion Control, July/August 1998.

Karr, J. R. 1991. "Biological integrity: A long-neglected aspect of water resource management." Ecological Applications, 1(1): 66-84.

Kaspersen, J. 2000. “Holding Something Back: Sediment Containment Measures.” Erosion Control, May/June 2000: 34-42.

Kaufman, M. M. 2000. "Erosion control at construction sites: The science-policy gap." Environmental Management, 26: 89-97.

Leopold, L. B. 1996. In Applied River Morphology by D. L. Rosgen, Wildland Hydrology, Pagosa Springs, Colorado.

Miller, J. R., P. J. Lechler, and M. Desilets. 1998. "The role of geomorphic processes in the transport and fate of mercury in the Carson River basin, west-central Nevada." Environmental Geology, 33(4): 249-262.

NRC. 1992. Restoration of Aquatic Ecosystems: Science, Technology and Public Policy. National Research Council, National Academy Press, Washington, D.C.

NRCS. 1998. Stream Corridor Restoration: Principles, Processes, and Practices. Natural Resources Conservation Service, Washington, D.C.

ORNL. 1992. Work Plan for the Independent Verification of the Monticello Remedial Action Project and the Monticello Vicinity Properties. Oak Ridge National Laboratory, Grand Junction, Colorado.

ORNL. 1998. Addendum to the Work Plan for the Independent Verification of the Monticello Remedial Action. Oak Ridge National Laboratory, Grand Junction, Colorado.

Paterson, R. G., et al. 1993. "Costs and benefits of urban erosion and sediment control: The North Carolina experience." Environmental Management, 17(2): 167-178.

Rosgen, D. L. 1994. "A classification of natural rivers." Catena., 22: 169-199.

Rosgen, D. L. 1996. Applied River Morphology. Wildland Hydrology, Pagosa Springs, Colorado.

Rosgen, D. L. 1997. River Restoration and Natural Channel Design, Sept. 29 through Oct. 10, Wildland Hydrology, Pagosa Springs, Colorado.

Smith, J. G., M. J. Peterson, and M. G. Ryon. 1996. An Ecological Investigation of a Vanadium and Uranium Mill Tailings Site (Draft, May 1996). Oak Ridge National Laboratory, Oak Ridge, Tennessee.

Stakhiv, E. 1996. U.S. Army Corps of Engineers. In Science and Technology Needs for Sustainable Water Resources in the 21st Century. EPA/ORNL Workshop, Chattanooga, Tennessee, May 21-23.

Stern, J. 1998. "The Green Line at Heart: Rancher Benny Martinez." In The Green Line, Summer 1998. Colorado Riparian Association, 9(2). 
USACE, 1994. Channel stability assessment for flood control projects. U.S. Army Corps of Engineers. EM 1110-2-1418. Washington, D.C. 
ORNL/TM-2001/7

\section{INTERNAL DISTRIBUTION}

1-19. N. Korte

20. C. A. Little

21-30. M. J. Wilson-Nichols
31. Central Research Library

32-33. Laboratory Records (OSTI)

34. Laboratory Records (RC)

\section{EXTERNAL DISTRIBUTION}

35. M. K. Tucker, U.S. Department of Energy, Grand Junction Office, 2597 B-3/4 Road, Grand Junction, CO 81503

36. J. D. Berwick, U.S. Department of Energy, Grand Junction Office, 2597 B-3/4 Road, Grand Junction, $\mathrm{CO} 81503$

37. D. R. Metzler, U.S. Department of Energy, Grand Junction Office, 2597 B-3/4 Road, Grand Junction, CO 81503

38. P. Mushovic, Environmental Protection Agency, Region 8, 999 18th St., Suite 500, Mal Stop 8HWF-FF, Denver, CO 80202-2466

39. D. Bird, Utah Department of Environmental Quality, Division of Environmental Response and Remediation, 168 North 1950 West, Salt Lake City, UT 84116 
1 